\title{
KATAR'DA KÜLTÜR, MIRAS VE MÜZE ÇALIŞMALARI
}

\author{
CULTURE, HERITAGE AND MUSEUM STUDIES IN QATAR
}

\section{Ceren Karadeniz ${ }^{*}$}

Öz

Dünya 2000'lerin ortasından itibaren Arap Körfezi'ndeki "yeni müzeleri” yakından izlemektedir. 1970'e kadar, Bahreyn, Birleşik Arap Emirlikleri, Kuveyt ve Katar gibi eski İngiliz sömürgelerinde müzelerin kültürel bir politika ile tanınmasını önerecek hiçbir gelişme yaşanmamıştır. 1960'ların sonlarında bölgede kültürel mirası gururla sergileyecek müzeler açılmaya başlamıştır. Katar'ın ulusal mirasını koruma, Arap kimliğini geliştirmeyi amaçlayan Katar Müzeleri, ülkenin bölgedeki gücünü, geleneksel bedevi yaşam tarzını, Al Thani hanedanının egemenliğiyle birlikte petrol sonrası modernleşme dönemini ve göçle birlikte gelişen yeni Doha kimliğini yansıtmaktadır. Bu gelişmelerin sonucu olarak Katar müzeleri, ulusal kimliği temsil eden nesneleri sınıflandırmakta; teknolojik tasarımlarla sunmakta ve cazibe merkezleri haline gelmektedir. Bu çalışmada, Arap Körfezi'ndeki müzeciliğin gelişiminden hareketle Katar'daki müzelerin amaç ve işlevlerine genel bir bakış sunmak amaçlanmaktadır. Bu amaç doğrultusunda Katar Ulusal Müzesi, İslam Sanatları Müzesi ve Mathaf Çağdaş Sanatlar Müzesi'nin uluslararası izleyici kitlesi için kendine özgü kimlikleri geliştirmek amacıyla miras nesneleri üzerinden izledikleri müzecilik yaklaşımı değerlendirilmiştir.

Anahtar Kelimeler: Müze, Müzecilik, Müze Mimarisi, Teknoloji, Katar.

\begin{abstract}
World has been closely monitoring the new museums in the Arabian Gulf since the mid-2000s. Until the 1970s, there were no developments in the old British colonies, such as Bahrain, the United Arab Emirates, Kuwait and Qatar which would largely promote cultural recognition of museums. In the late 1960s, studies for museums concerned about historical development in the region. Qatar Museums aim to emphasize the need to preserve Qatar's national heritage and to develop Arab identity. These museums classify the objects representing the identity of Qatar; technology with digital design that push the boundaries and make these regions the center of attraction. The aim of this study is to provide an overview of the forms and functions of museums in Qatar. For this purpose, Qatar National Museum, Museum of Islamic Arts and Mathaf Museum of Contemporary Arts were evaluated through Qatar museums' local approach to cultural heritage to develop unique identities for the international audience.
\end{abstract}

Keywords: Museum, Museology, Museum Architecture, Technology, Qatar.

Olgu Sunumu // Başvuru tarihi: 08.08.2019 - Kabul tarihi:18.12.2019.

*Arş. Gör. Dr., Ankara Üniversitesi Güzel Sanatlar Fakültesi Müzecilik Bölümü, ckaradeniz@ankara.edu.tr, https://orcid.org/0000-0001-5773-8557. 


\section{Giriş}

Yüzölçümüne bakıldığında küçük bir emirlik olan Katar, 1971'de bağımsızlığını kazanmış; petrol ve doğalgaz rezervleriyle büyük bir servet elde etmiştir. Emirlik son on yılda zenginliğinin yanı sıra küresel aşamada sahne olduğu müzecilik faaliyetleriyle; uluslararası medya projelerine ve çağdaş batı sanatına yaptığı yatırımlarla ve yurtiçi ve yurtdışındaki çok sayıda kültür projesine finansal destek sağlamasıyla da dikkat çekmektedir. Şeyh Hamad bin Khalifa Es-sani (1995-2013)'nin müzelere ve markalaşmaya yatırım yaparak Katar'ın geleceğini tayin etmeye soyunması Emirliğin markalaşma stratejisini ayrıntılı olarak planlayacağı dizi dikkat çekici projeyi gündeme getirmiştir. Markalaşma stratejileri kapsamında ulusal içerikte kültürel, sanatsal, bilimsel ve sportif etkinlikler düzenleyerek ulusal Katar kimliğini inşa etmeye ve aynı etkinlikleri uluslararası platformda destekleyerek küresel görünürlüğü artırmaya odaklanan projeler Khalifa Al Thani döneminin icraatlarıdır. Bu süreçte 1996'da Al Jazeera Medya Ajansı'nın kurulması ve ABD destekli Orta Doğu ve Kuzey Afrika bölgesel ekonomi toplantısının 1997'de Doha'da gerçekleşmesi Emirliğin adını duyuran ilk projeler olmuştur. Katar’ın marka stratejisinin aynı zamanda ekonomik hedefleri de içermesi ülkenin petrol üretimini ülke markasının ve uluslararası imajının parçası haline getirmesini de sağlamıştır. İslam Konferansı Zirvesi'nin 2002' de Doha'da düzenlenmesi ekonomik gelişmeyi ve uluslararası görünürlüğü artırmıştır. Aynı dönemde Katar'ın marka çalışma alanlarından biri de spor olmuştur. Uluslararası spor otoritelerini çekmek amacıyla her yıl Katar Uluslararası Rallisi düzenlenmeye başlanmış, ünlü sporcuların katıldığı tenis turnuvaları hazırlanmış ve birçok sporcuya Katar vatandaşlı̆ı verilerek çeşitli turnuvalarda boy göstermeleri sağlanmıştır. Ulusal kültür ve sanat politikalarının yürütülmesinden sorumlu Katar Müzeleri Birliği'ne bağlı Toplum ve Sanat Birimi'nin, 2006'da Dünya Kupası Organizasyonunun başkanlığını yapan Marco Materazzi ve Zinedine Zidane gibi ünlü futbolcuların heykellerini Doha kentinin çeşitli noktalarına yerleştirmesi ve nihayetinde FIFA 2022 Dünya Kupası'nın Katar'da düzenlenmesine karar verilmesiyle Katar ulusal kimliğinin sportif platformlarda da tanınırlığı artırılmaya başlandığı söylenebilir. Kazerouni (2014)'ye göre, tüm bu gelişmeler, ABD ile ilişkileri sürdürmek için siyasi ve kültürel diplomasi politikası izleyen emirlerin dışa dönük uluslararasılaşma gündeminin önemli bir parçasıdır ve Doha kentinin büyük bölümünü bir bölgesel kültür merkezi haline getirmiştir (Batty, 2012). 
Aynı yıllarda ekonomik, bilimsel ve sportif etkinliklerin yanı sıra sanatsal etkinliklerde de adından söz ettirmeye hazırlanan Katar, bünyesindeki modern, çağdaş ve İslami sanat koleksiyonlarını gündeme almış; uluslararası sanat piyasasını hareketlendirerek adını duyurmaya çalışmıştır. Artun (2015:13), Arap Körfezi'ndeki ülkelerin kültür ve turizm yatırımlarında birbirleriyle büyük bir rekabet içinde olduklarını da ifade etmektedir. Öyle ki, şeyhlerin Birleşik Arap Emirlikleri (BAE)'nin başkenti Abu Dhabi'yi ülkenin sanat merkezi ve Dubai'yi ise paranın ve turizmin merkezi yapmaya kararlı oldukları bilinmektedir. Louvre ile Guggenheim gibi müzelerin Abu Dhabi'de birer şube açma girişimleri emirlerin BAE'yi Körfezin sanat başkenti haline getirme çabaları olarak yorumlanmaktadır. Artun (2015:16), BAE'de sanatsal yapılanmanın merkezi olan Abu Dhabi'nin şimdiden çağdaş sanat koleksiyonlarına 520 milyon dolar ayırdığını belirtmektedir. Dolayısıyla sermaye çağdaş ve çarpıcı kurumlar olarak tanımlayabileceğimiz müzelerin yeni adreslerinin Arap Körfezi olduğuna işaret etmektedir. Buna karşın yüksek fiyatlı sanat koleksiyonları ve küreselkültürel sanat etkinlikleri Katar'daki sanat galerileri tarafından benimsenmiş; Şeyh EsSani'nin başı çektiği koleksiyonerlik ve müzecilik çalışmaları Katar kültür endüstrisinin de merkezine yerleşmiştir (Artun, 2014).

\section{Amaç ve Yöntem}

Arap Körfezinde başta Birleşik Arap Emirlikleri olmak üzere Katar ve Umman gibi ülkelerde kültür, sanat ve spor etkinlikleri aracılı̆̆ıyla ulusal kimlik inşasını gerçekleştirme ve ülkenin uluslararası platformda tanınırlı̆ı̆ı artırma politikalarının yola açtığı müzeleşme süreçlerini Katar özelinde incelemeyi amaçlayan bu çalışmada, nitel araştırma yöntemlerinden betimsel tarama modelli kullanılmış veriler doküman inceleme tekniğiyle ve Katar’a gerçekleştirilen kişisel ziyarette toplanan görsel ve yazılı dokümanların analiziyle toplanmıştır. Doküman incelemesinde temel amaç, araştırılması hedeflenen olgu veya olgular hakkında bilgi içeren yazılı materyallerin analiz edilmesidir (Yıldırım ve Şimşek, 2006). Çalışmada doküman inceleme bağlamında aynı zamanda Mason (2006:28) tarafından da vurgulanan "müzeye bir metin olarak yaklaşma" yöntemi benimsenmiştir. Bu yaklaşımda müze vb. kültür kurumlarına ilişkin özellikler bir metin olarak ele alınarak okunmakta; müzenin yorum ve anlatım biçimleri, müzecilik yaklaşımları ve stratejileri, sergi tasarım elemanları (etiketleme, aydınlatma) ve iç-dış mimari özellikleri bağlamında bütüncül olarak değerlendirilmektedir. 


\section{Bulgular ve Yorum}

\subsection{Katar'da Kültürel Miras Çalışmalarının ve Müzeciliğin Kısa Tarihi ve Gelişimi}

1971'de İngiliz korumacılığından çıkmasıyla birlikte kendi kalkınma hamlesini ve kültür politikasını belirleyen Katar, aynı yı Birleşmiş Milletlere katılmıştır. Eski Emirlik Sarayı bu gelişme döneminde önemli bir bileşen olarak kültür merkezi biçiminde kullanılmış ve yeni yöneticinin yerel mirasa, geleneğe ve tarihe olan bağlılı̆ı̆ı göstermede önemli bir rol oynamıştır. Bu gelişmeler yalnızca tarihi, kültürü ve mirasıyla aile ilişkileriyle olan temaslarını inşa eden genç nesil Katar halkı için önemlidir; bu aynı zamanda Katar tarihinin daha genç kuşaklara aktardığı önemli bir anlatıdır. 70’li yıllarda ülke için resmi bir tarihi arşiv yoktur ve ülke tarihini anlatan çok az belge elde kalmıştır. Önemli olaylar hakkında tarihi bilgiler genellikle sözlü olarak iletilmiştir. Bu nedenle, Katar'ın siyasi ve kültürel tarihiyle ilgili anlatıları ve ulusal kültürün unsurlarını yönetmek için müzelere ihtiyaç duyulmuştur (Al Mulla, 2013:65).

Bouchenaki (2011:98)'ye göre, 1970'lere kadar, Bahreyn Krallı̆ı, Birleşik Arap Emirlikleri, Kuveyt ve Katar gibi, yakın zamanda bağımsızlık kazanan eski İngiliz sömürgelerinde müzelerin büyük ölçüde kültürel bir politika ile tanınmasını önerecek hiçbir gelişme yaşanmamıştır. 20. yüzyılın sonuyla ve yeni binyılın başlamasıyla birlikte, kültürel gelişimin vurgulanmasının ve bu bağlamda özellikle yeni müzelerin oluşturulmasının ülkeler için öncelik haline geldiği ulusal politikalar benimsenmiştir. Arap ülkelerindeki müzelerin çoğu hala sosyal bağlamlarından izole edilmiş nesneler müzesi görünümüyle; taş, seramik, cam, işlemeli ahşap, deri, el yazması gibi geleneksel nesneleri "nesne odaklı" bir yaklaşımla sergilemeyi sürdürmektedir. Rice (1977:80-81), ilk kez 1960'ların sonlarında bölgede tarihsel gelişim için endişe duyan ve kültürel mirası gururlanmak için sergilemek isteyecek müzelerin açılmaya başlandığını ifade eder. Özellikle Katar ve Kuveyt'te art arda açılan bu müzeler birçok disiplinin ürünlerinin iç içe geçmiş durumda olduğu kurumlar olarak fark yaratma çabasındadır.

Katar'ın resmi ulusal tarihi ve mirası yakın tarih olarak kabul edilen Al Thani ailesinin egemenliği ile 19. ve 20. yüzyıl başlarında bölgedeki İngiliz ve Osmanlı güçlerinin egemenliğine odaklanmaktadır. Al Thani ailesinin egemenliğiyle birlikte Katar'da özellikle bu ailenin hüküm sürdüğü alanlarda kültürel ve doğal mirası vurgulayacak çok sayıda ve çeşitlilikte bilimsel çalışma yapılmıştır. Ulusal tarihin de odak noktası ilan edilen bu alanlar 
arasında Katar Müzeleri ve Kopenhag Üniversitesi tarafından arkeolojik kazısı yürütülen 18. yüzyıl ticaret ve yerleşim alanı olan ve UNESCO Kültürel Miras Alanı ilan edilen Al Zubara önemli bir yere sahiptir. Katar Ulusal Müzesi'nin ilk yerleşim yeri ve yeni Ulusal Katar Müzesi'nin bulunduğu merkez de arkeolojik araştırmaların sürdürüldüğü diğer alanlardır. Al Zubara ve yakınındaki müzeler, Al Thani ailesinin öyküsünü, bölgedeki diğer kabilelerin ve ailevi gerilimlerin ülke tarihindeki rolünü vurgulayan bir anlatı sunmaktadır. Günümüzde Katar'daki kültür projelerine genellikle Al Thani ailesinin üyeleri başkanlık etmektedir ve Katar müzelerinde sergilenen koleksiyonlar bu aile üyeleri tarafından toplanmıştır (Kamrava, 2013:123-124).

Rice (1977:79), Katar'da 23 Haziran 1975'te, ilk kez kamu binalarına ev sahipliği yapmak üzere inşa edilmiş olan Eski Saray'da ziyarete açılan Katar Ulusal Müzesi'ni ulusal düzeyde müzecilik gelişmelerine ilk örnek olarak göstermiştir. Bu müze geleneksel ve modern mimari unsurların bir arada kullanıldığı; tarihi bir saray binasıdır. Devralındığında ayrıntılı bir ihtiyaç analiziyle mimari düzenlemesi yapılan müze; bölgenin kültürel ve mimari geleneğine saygılı yeni bir tasarım haline gelmiştir. Söz edildiği üzere 1970'den sonra bölgede ulus inşası sürecinin bir parçası olan müze vizyonu ve misyonuyla Katar tarihine ve geleneklerine adanmıştır. Çölde yaşayan göçebe Bedevi kabilelerinin fotoğraflarını ve eşsiz bir madeni para koleksiyonunu barındıran müze, 1970'lerin yeni müzecilik anlayışını devam ettirircesine bugüne seslenmiştir. Katar'da devlet eliyle yürütülen kültür nesnesi toplama süreçleri, küresel tüketim ve ulusal uyum için yeni bir Katar kimliği ve bir ulusal müze inşasıyla bağlantılıdır (Exell, 2016:269). Bu girişim bireysel düzeyde toplama, hızlı gelişme ve küreselleşme karşısında kaybolanı koruma ve yerel otoriteyi benimseyerek gelenekleri temsil etme arzusuyla ilişkilendirilebilir. Katar Ulusal Müzesi için oluşturulan ulusal koleksiyonlar bu süreci kurumsallaştırmış ve yeni inşa edilen "Katar" kimliğini temsil eden nesneler yeniden sınıflandırılmıştır (Zahlan, 1989:127).

1970'den sonra Katar'da petrol, gaz ve diğer endüstrileri yönetmek için farklı milletlerden her düzeyde eğitim almış göçmenlere ihtiyaç duyulmuştur. Bu gelişmeler Fibiger (2011:188)'e göre, Batılı yaşam biçimini ülkeye yerleştirmeye başlamış; geleneksel Katar kimliğinin dönüşmesine neden olmuş ve aynı zamanda yerel kimlikleri korumaya yönelik bir motivasyona da yol açmıştır. Bu kaygılardan hareketle Şeyh Faisal Bin Qassim Al Thani, geçmişe tutunma isteğiyle yerel kültüre özgü pek çok nesnenin toplanmasına ön ayak 
olmuş; bu nesnelerin korunması ve sürdürülebilirliklerinin sağlanması için uyarılarda bulunmuş, genç kuşağın Katar'ın tarihi hakkında bu nesneler yoluyla yetiştirilmesi amacıyla 1970'lerin sonunda peşi sıra farklı türde müzelerin açımasını da sağlamıştır. 1960'larda Katar hükümetinin, bölgede daha önce çalışmış olan İngiliz arkeolog Beatrice de Cardi'yi arkeolojik çalışmalar yürütmesi amacıyla ülkeye davet etmesi ve De Cardi'nin, Neolitik Dönemin başlangıcından günümüze Katar'ın hikâyesini anlatacak nesneleri gün yüzüne çıkarmasıyla birlikte Katar'da müzecilik çalışmaları da resmi olarak başlamıştır.

Katar Ulusal Müzesi başta olmak üzere ilk açılan Katar müzeleri iki amaca odaklanmıştır: Geçmişe bağlı farklı bir ulusal kimlik oluşturmak ve Katar'da değişen yaşam tarzını yakından izleyerek mevcut yaşam biçimini korumak. Her iki amaç da Arap Körfezi'ndeki yeni ulus-devletlerin kendilerini diğer devletlerden ayırmalarını ve kendilerine özgü ulusal kimlikler oluşturmalarını sağlamıştır. Katar'da ulusal müzelerin kurulması sürecinin en çarpıcı çıktısı 1975 'te eski kraliyet sarayı binasında açılan Katar Ulusal Müzesi'nin izleyiciyle buluşmasıdır. Arkeolojik nesnelerden bedevilerin gündelik yaşam nesnelerine kadar farklı içerikte kültürel miras unsurlarının sergilendiği müzedeki nesneler Bahreyn Ulusal Müzesi (1971) ve Suudi Arabistan'daki Ulusal Müzede (1974) olduğu gibi, 1950 'lerden bu yana bölgede çalışan yabancı arkeologlar tarafından toplanmıştır (Fibiger, 2011:189).

Raban (1987:180), Katar'da 1950'den önce gerçekleşen her şeyi "efsane" olarak adlandırmakta ve 1950 yılını Katar için önemli bir tarihi ve kültürel kırılma noktası olarak görmektedir. Katar'daki hızlı değişimin tarihsel ve çağdaş bağlamının, bazı geçmişlerin "efsane" olarak algılanmasıyla daha da artmış olan miras kimliği konusunda bir belirsizliğe yol açtığı söylenebilir. Bu algı somut, genellikle anıtsal ve tarihsel bir geçmişe sıkı sıkıya bağlı kalmaya devam eden, sözlü tarihlerin ve yaşam uygulamalarının gerçekliğini özümseyebilecek ve doğrulanamayan baskın "miras söylemi”dir. Katar’ın efsane tarihi doğrudan Al-Thani ve ailesiyle ilişkilendirilmektedir. Katar'da miras alanında yaşanan gelişmeler, yoğun modernleşmenin kente etkisi ve yaşam biçiminin hızla değişmesiyle ilişkili olarak mirasın kültürel bağlamda nasıl kavramsallaştırıldığını ve "risk altında" olduğu için farklı otantik gelenek biçimlerine dönüştürüldüğünü sorgulama konusunda eşsiz fırsatlar sunmaktadır. Dolayısıyla Katar Ulusal Müzesi, Katar ve çevresindeki Körfez Ülkeleri'nde somut ve somut olmayan kültürel mirası temsil eden geleneksel bir müze olarak aynı 
zamanda bu mirasın nasıl geliştirilebileceğine ilişkin tartışmaların da ilk merkezidir. Müze kurulduğundan beri, yerel kimliğin sunulmasına ve onaylanmasına ilişkin yöntemlerde kavramsal bir değişiklik yapmıştır. Ulusal Müze, yerel kültürü evrensel kültürel miras olarak sentezleyen "tipik" ve "otantik" eserlerin sunulduğu bir kurum halini almıştır.

1995'te Hamad bin Khalifa Al Thani ülke yönetimini ele alarak, 2000'li yıllarda Katar'ın uluslararası kültürel ve turistik kalkınma sahnesine çıkmasına odaklanmıştır. 2000'den itibaren Katar'da kültürel mirasa ilişkin yatırım ve yaptırımlarda artış yaşanmıştır. 1998 yılında Katar Yüksek Kültür, Sanat ve Miras Konseyi'nin kurulması ve 2000 yılında Katar Turist Birimi'nin faaliyete geçmesi bu gelişmelere örnektir. Katar'da BAE gibi petrol endüstrisine dayalı ekonomisini akılcı gelecek yatırımlarıyla turizm ve kültür sektörlerine kaydırmayı uygun görerek, alternatif sektörler oluşturmayı planlamıştır. 2005'te ülkedeki tüm müzeler için Batı tarzında etik kodları benimseyerek uygulayacak müzeleri bir araya getirecek Katar Müzeler Birliği'nin kurulmasının ardından 2008'de dünyaca ünlü mimar I. M. Pei'nin tasarladığı Katar İslam Sanatları Müzesi'nin ziyarete açılması Katarın uluslararası kültür ve sanat platformunda önemli bir role soyunduğunu göstermiştir. Bununla birlikte Aralık 2010'da Mathaf: Arap Modern Sanat Müzesi'nin ziyarete açılması ve yerleşke olarak birçok yabancı üniversitenin Doha'daki yeri olarak bilinen Hamad Bin Khalifa Üniversitesi kampüsünün eteklerinde bulunan yenilenmiş bir okul binasına yerleşmesi Katar'ın uluslararası sanat camiasında söz sahibi olma istediği gözler önüne sermiştir. Artun (2017:147), bu durumun bir tesadüf olmadığını belirtirken; günümüzde çağdaş sanatın en zengin koleksiyonlarının Katar Emiri'ne ait olduğunu vurgulamaktadır. Artun $(2017,147)$, dünyanın kültür- sanat başkentlerinin, 16. yüzyıldan başlayarak, sırasıyla Floransa, ondan sonra Paris, daha sonra da New York olarak kabul edildiğini; şimdi ise Doha'nın ön planda olduğunu söyleyerek; günümüzde bir "Dubai Rönesansı"nın yaşandığından söz etmektedir. Birleşik Arap Emirlikleri ve Katar gibi bu şeri monarşilerin, güçlerini önemli ölçüde sanatı özelleştirerek sağladıklarını da eklemektedir. Bu söylemi onaylarcasına Katar'ın yeni müzeleri 2019 yılının mart ayında ziyarete açılan ve Birleşik Arap Emirlikleri'ndeki Louvre Abudhabi'nin de mimarı olan Jean Nouvelle'in tasarladığı Katar Ulusal Müzesi (orijinal Ulusal Müze tasarımını da içine almıştır) ile yerel mirastan ziyade mirası ulus ötesi olarak gören küreselleşme rejiminden de etkilenen yapılardır. 


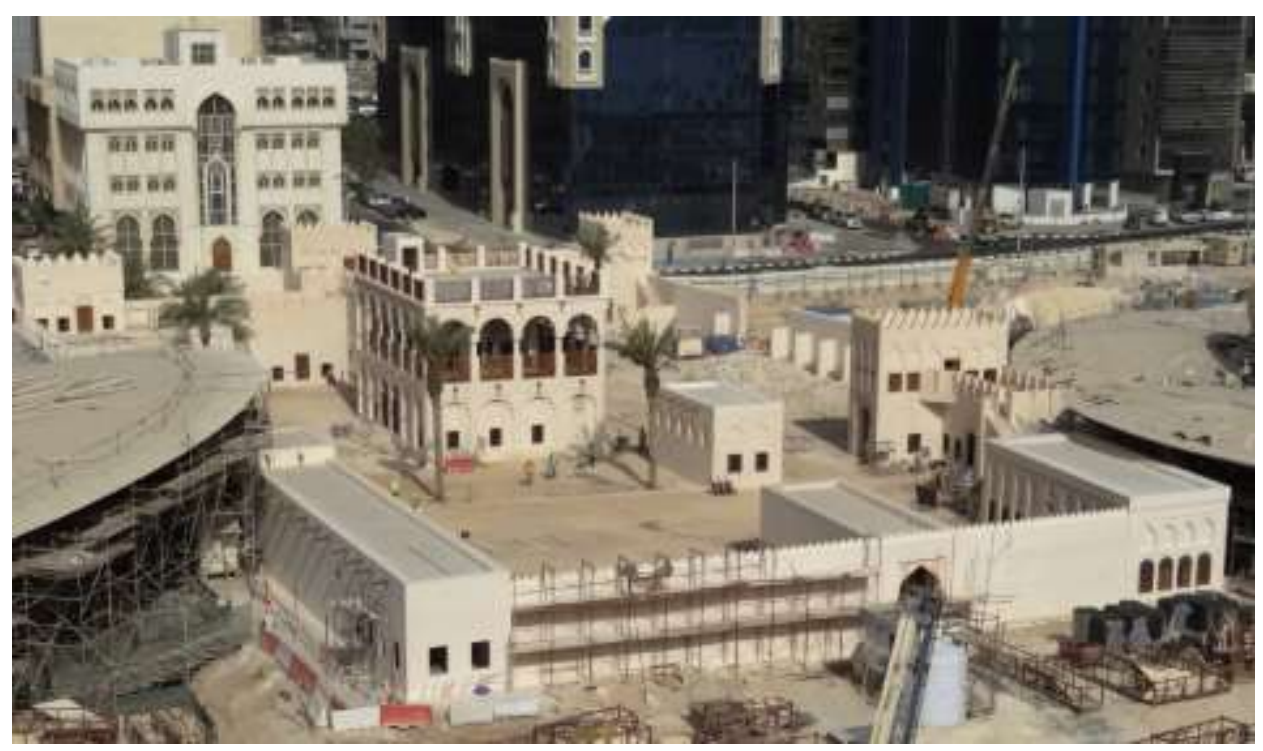

Görsel 1. Hamad bin Khalifa Al Thani'nin sarayı Katar Ulusal Müzesi'ne ev sahipliği yapmıştır.

Ulusal müze girişimi, Şeyhin kişisel koleksiyonunun ulusal mirası inşa etmek bağlamında sergilenmesinin sağlanması açısından önemlidir. Şeyhin 17.000 'den fazla nesneden oluşan (eski paralar, otomobiller, radyolar, dini malzemeler vb.) özel koleksiyonu başkent Doha'da koleksiyona ev sahipliği yapması için inşa edilmiş bir müzeye yerleştirilmiş ve ülkenin yöneticilerinden birinin koleksiyoner olarak zevklerine, değerlerine ve dönemin sosyal ve tarihi koşullarına ayrıntılı bakmayı hedeflemiştir. Bu koleksiyon Katar'ın kentsel refaha ulaşması ve moderniteye geçişte geride bıraktığımız yarım yüzyıl boyunca politik, ekonomik ve siyasi bağlamda yaşadığı hızı değişimi yansıtırken aynı zamanda, idealize edilmiş bir geçmiş için nostaljiyi vurgulamakta ve yerel bilginin ve otorite sistemlerinin kaybedilmesinden duyulan kaygıya da yer vermektedir. Bu koleksiyon aynı zamanda geleneksel inci avcılı̆̆ını, bedevi halkın yaşantısını, çöl yaşantısından kent sistemine geçerken yaşanan zorlukları, petrol ve gaz bakımından zengin olan bu ülkede kaynakları korumanın zorluğunu da temsil etmektedir (Wright, 2011:117). Şeyhin koleksiyonuna benzer çok sayıda koleksiyon daha önceki geleneksel yaşam tarzlarının sadeliği ve kendine yeterliliğini vurgulamaya çalışırken; birçok koleksiyon ise, kabile ve aileye odaklanmakta; misafirperverlik vb. değerlerle gurur duyan sunumlarla, kolay yaşam ve zengin hayat arasındaki zıtlıkları da öne çıkarmaya çalışmaktadır (Ulrichsen, 2011:109-110).

Katar Ulusal Müzesi ilk açıldığı dönemden bu yana Arap dünyasının homojen bir bütün olduğunu vurgulamaktadır. Müze, belgelediği ve içerdiği kültürel mirası çağdaş müzecilik yaklaşımlarıyla bir araya getirmeyi planlayarak Körfezin dikkat çeken 
müzelerinden biri olarak amaçlamaktadır (Exell ve Rico, 2013:675). Ulusal Müze 1980'de, Doha'da "miras binaları" olarak bilinen ve on dokuzuncu yüzyılın sonlarından kalma binalara ait özenle korunmuş örneklerin gerçekleştirildiği bir yenileme projesiyle Agha Khan ödülünü kazanmıştır. Ödülün kazanılmasını sağlayan proje Souq Waqif Bölgesindeki inci tüccarlarına ait evlerin restore edilerek müze binasına eklenmesidir.

1980'lerin sonunda Katar Ulusal Restorasyon Birimi, Doha'daki çok sayıda tarihi camiyi ve Souq Waqif Bölgesindeki diğer tarihi binaları restore etmiştir. Buna rağmen kültürel kimlikte olduğu gibi, Katar'ın yerel mimarisi de hızlı kentsel gelişim ve kentin yeniden şekillenmesi tehlikeleriyle karşı karşıya kalmıştır. 1980'den itibaren Katar'ın miras yapılarının restorasyonlarında kültürel ve mimari üslubun kaybedilmesini engellemek için "yeni bir mimari dil" oluşturulması uygun bulunmuştur. Souq Waqif'in yanı sıra, birçok bölgede Ulusal Müze öncülüğünde Doha'nın Kalbi Projesi başlatılmıştır. Proje kapsamında ilan edilen yeni mimari dil, birleşik bir mimari yaklaşımla yerel mirası ve ulusal kültürü canlandıran ortak bir DNA kurgulayarak kültürel miras yapılarını yenilemek için kullanıımıştır. Bu gelişmeler birçok Katarlı tarafından mirasın korunması kapsamında değerlendirilip benimsenirken, bir kesim tarafından ise küresel yaklaşımlardan etkilenerek Katar'ın mimari çehresini değiştirdiği için eleştirilmektedir.

Merrick (2008)'e göre, yeniçağın en çarpıcı sanat eserlerinden biri olarak kabul edilebilecek Katar Ulusal Müzesi Körfezdeki mimari zaferlerden biridir. Bilbao'daki Guggenheim Müzesi'nin açtığı "yeni müze mimarlığı” eğiliminin en son ve çağdaş örneğidir. Abudhabi Louvre'un ardından turizmin gözünü Arap Körfezi'ne dikmiştir ve BAE'de benzer içeriklerde açılacak Zayed Müzesi ya da Abudhabi Guggenheim Müzesi'nin merak ve heyecanla beklenmesine sebep olmaktadır. Ulusal Müze titanyum kaplama cephesiyle yeni müzelerin "nasıl görünmesi gerektiği" iddiasının önemli bir temsildir. Çağdaş müzecilik anlayışının mimari, pazarlama, toplumsal çalışmalar ve tanıtım faaliyetlerini kapsayan yeni alanlara vurgu yapması, postmodern müzecilik kavramının ortaya çıkmasına neden olmuş; bu anlayış müzeyi ulusal kimlik ve toplumsal hafızanın gelecek kuşaklara aktarıldığı, kutsal ve muhafazakâr mekân olarak tanımlayan modern müzecilik anlayışının tam tersini simgelemiştir. Dolayısıyla bu dönem ulusal kimliği yansıtan ifadeleri de içeren mimari üsluplara sahip, büyük ölçekli ve görkemli müze binalarını izleyiciyle tanıştırmıştır. Bu özellikleriyle öne çıkan Ulusal Müze Merrick (2019:67)'e göre, Katar'ın tarihi ve ulusal 
kültürünü üç boyutlu bir yanılsama oluşturarak yeni bir yorumla sunmayı başarmaktadır. Bina "çöl gülüne" atıf yapacak şekilde titanyum kaplı dış cephesini oluşturan 500 diskten oluşturulmuştur. Katar'ın kıyı şeridinde kum ve tuzun birleşimiyle ve tuzlu suyun buharlaşmasıyla oluşan bir mineral olan çöl gülü, ülkenin sembollerinden biridir. Mimar J. Nouvelle, Katar'ın içerdiği zıt özellikleri sembol bir elementle anlatmayı amaçlamıştır. Çöl gülünün kristalize yapısı aynı zamanda milenyumu ve geleceği de temsil etmektedir.

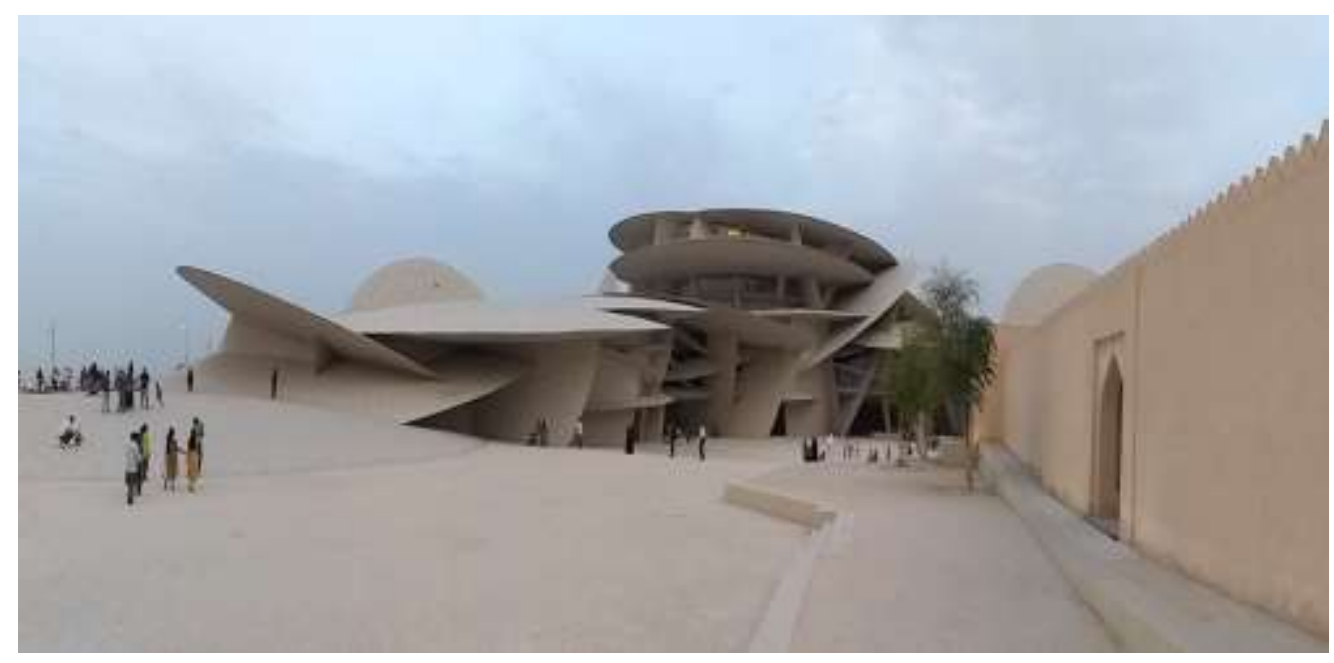

Görsel 2. Katar Ulusal Müzesi, 2019.

Müzenin içi de dışı gibi sürprizlerle doludur. Ziyaretçinin dikkatini çekecek duvar ve kat formları, uzaya aitmiş hissi yaratan dış görünüm, farklı biçimdeki tavanlar ve bir sonraki adımda ne ile karşılaşacağınızı bilmediğiniz merak uyandırıcı koridorlar tasarımın en belirgin özellikleridir. Müzenin dış yüzeyinde yer alan diskler 76.000 sağlam geometrik panelle kaplanarak yapıda bir desen bütünlüğü elde edilmiştir. Binanın iç ve dış yüzeyinde toprak rengi hâkimdir. Kervansarayı andıran iç avluda jips taşı kullanılarak müzenin bir çölde kurulmuş gibi görünmesi amaçlanmıştır. Bu bölümdeki tasarım Katar'ın ulusal kültürünü modernleşmeyle birlikte sürdürüyor olduğunun bir dışa vurumu olarak kabul edilebilir. 


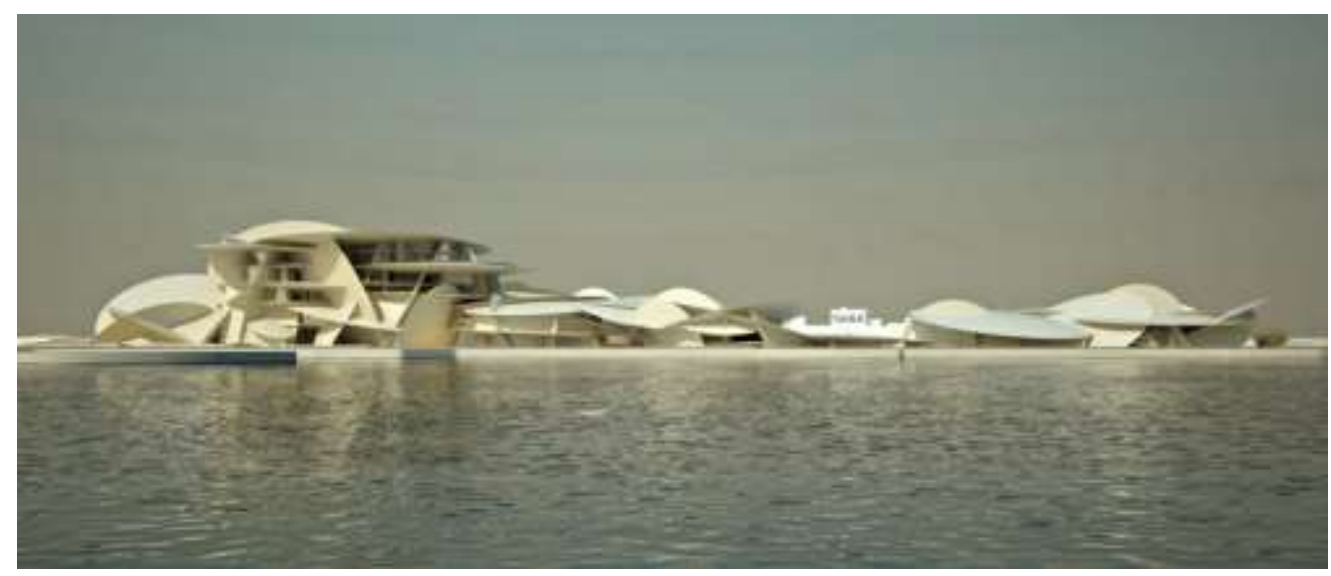

Görsel 3. Katar Ulusal Müzesi, 2019.

Müzenin mimari tasarımı, konsepti ve yönetim birimleri ile ilgili tüm çalışmalar Nouvelle ve Sheika Amna bint Abdulaziz bin Jassim Al Thani iş birliğinde gerçekleştirilmiştir. Çölün güzelliğini, otantik yerel mimariyi ve Katar'ın modernliğini aynı potada buluşturan bir yapıyı tasarlama hayaliyle kurulan müze, şaşırtıcı bir üç boyutlu tasarım halini almıştır. Öyküsünü 12 galeride anlatan müzenin her galerisi izleyiciyi Arap şiirinin ünlü örneklerinden bir dize ile başlamakta ve tarih şeridine oturan bir görsel veya yazılı metinle desteklenmektedir. Müze galerilerindeki duvarların büyük bölümü aynı zamanda ekran olarak kullanılmakta ve müzenin anlatısını zenginleştirecek şekilde tematik olarak hazırlanan videoları ve yansıları izleyiciyle buluşturmaktadır. Sergi çağdaş müzeciliğin bir gereği olarak dokunabileceğiniz, koklayabileceğiniz ve hissedebileceğiniz elemanlarla zenginleştirilmiştir. Her galerinin sonunda müze eğitimini destekleyecek biçimde çocukların aileleriyle birlikte nesneler aracılığıyla öğrenmelerine olanak tanıyan etkileşimli ve dokunmalı (hands-on) çocuk bölümleri oluşturulmuştur. Talboys (2006:24), müze eğitimini, müzelerin mevcut koleksiyonlarını kullanarak ziyaretçilerde merak, ilgi ve heyecan uyandıracak ziyaretçi merkezli eğitim programları ve uygulamaya olanak sağlayan etkinlikler hazırlama süreçleri olarak tanımlar. Dolayısıyla öğrenmeyi destekleyen yardımcı malzemelerin müze içinde sık kullanımı çağdaş müzecilik yaklaşımlarıyla örtüşmektedir. 
SDÜ ART-E

Güzel Sanatlar Fakültesi Sanat Dergisi Aralık'19 Cilt:12 Sayı:24 ISSN 1308-2698

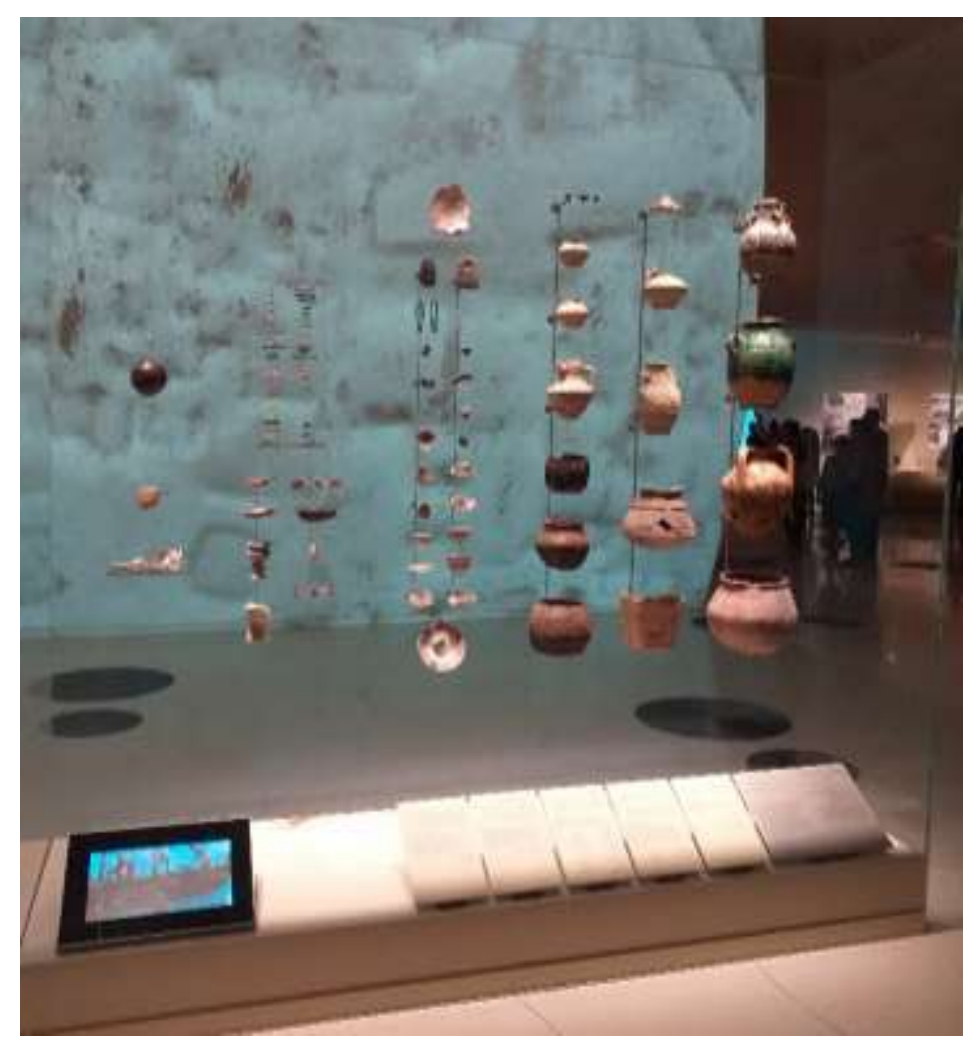

Görsel 4. Katar Ulusal Müzesi arkeoloji koleksiyonuna ilişkin sergi tasarımı, 2019.

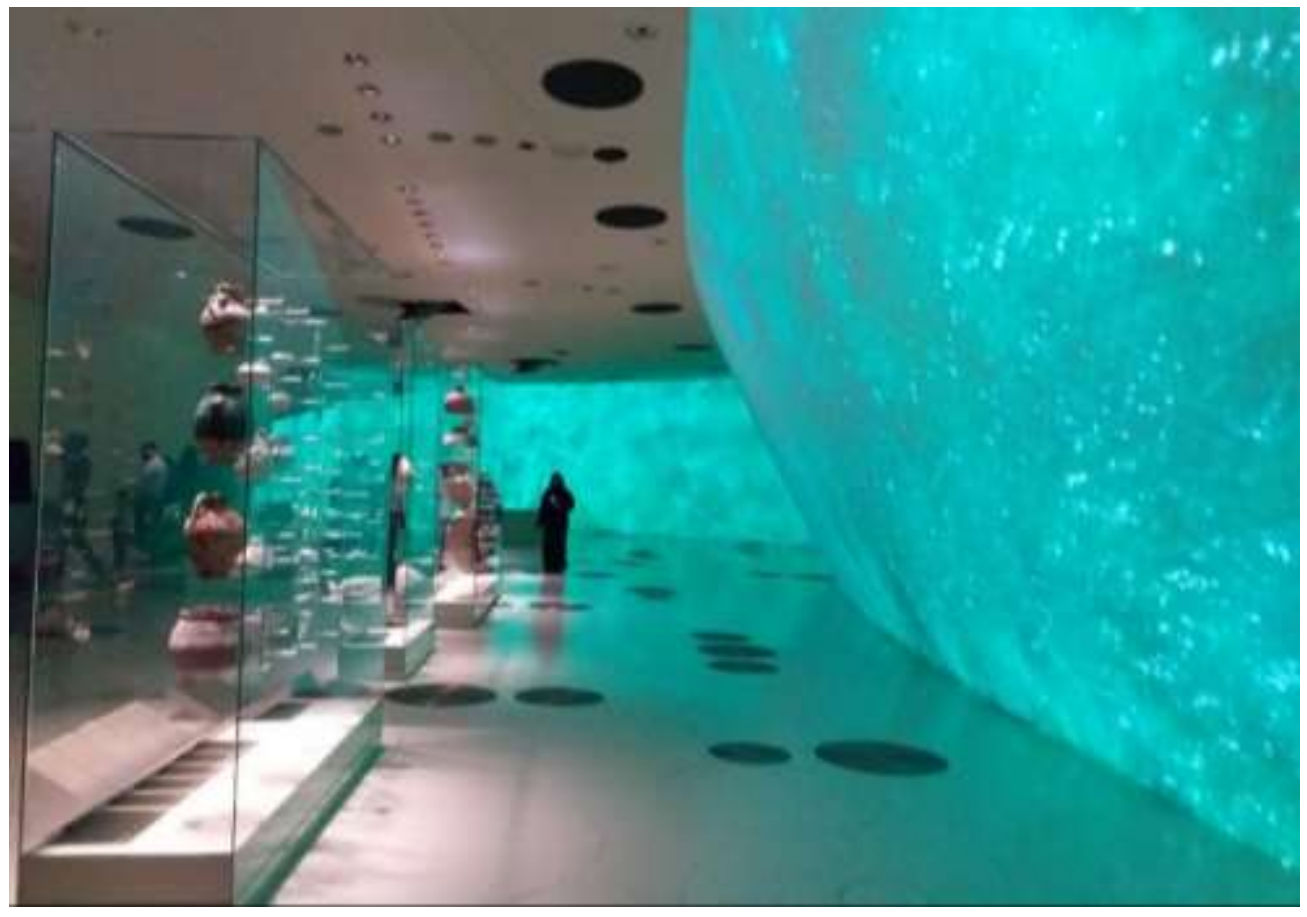

Görsel 5. Projeksiyonla zenginleştirilmiş müze duvarları, 2019. 
SDÜ ART-E

Güzel Sanatlar Fakültesi Sanat Dergisi Aralık'19 Cilt:12 Sayı:24 ISSN 1308-2698

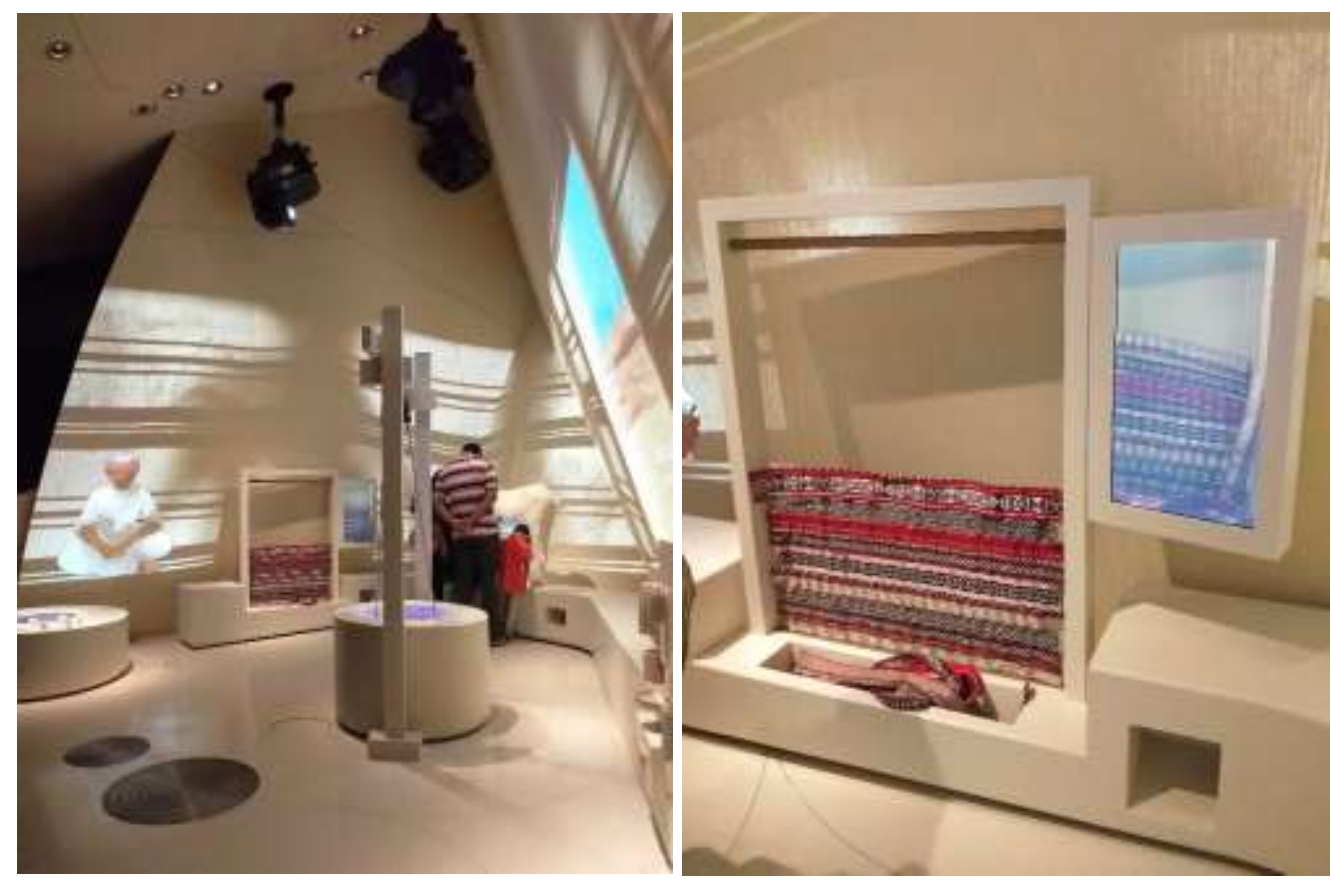

Görsel 6 ve 7. Katar'da dokuma kültürüne ilişkin etkileşimli çocuk bölümü, 2019.

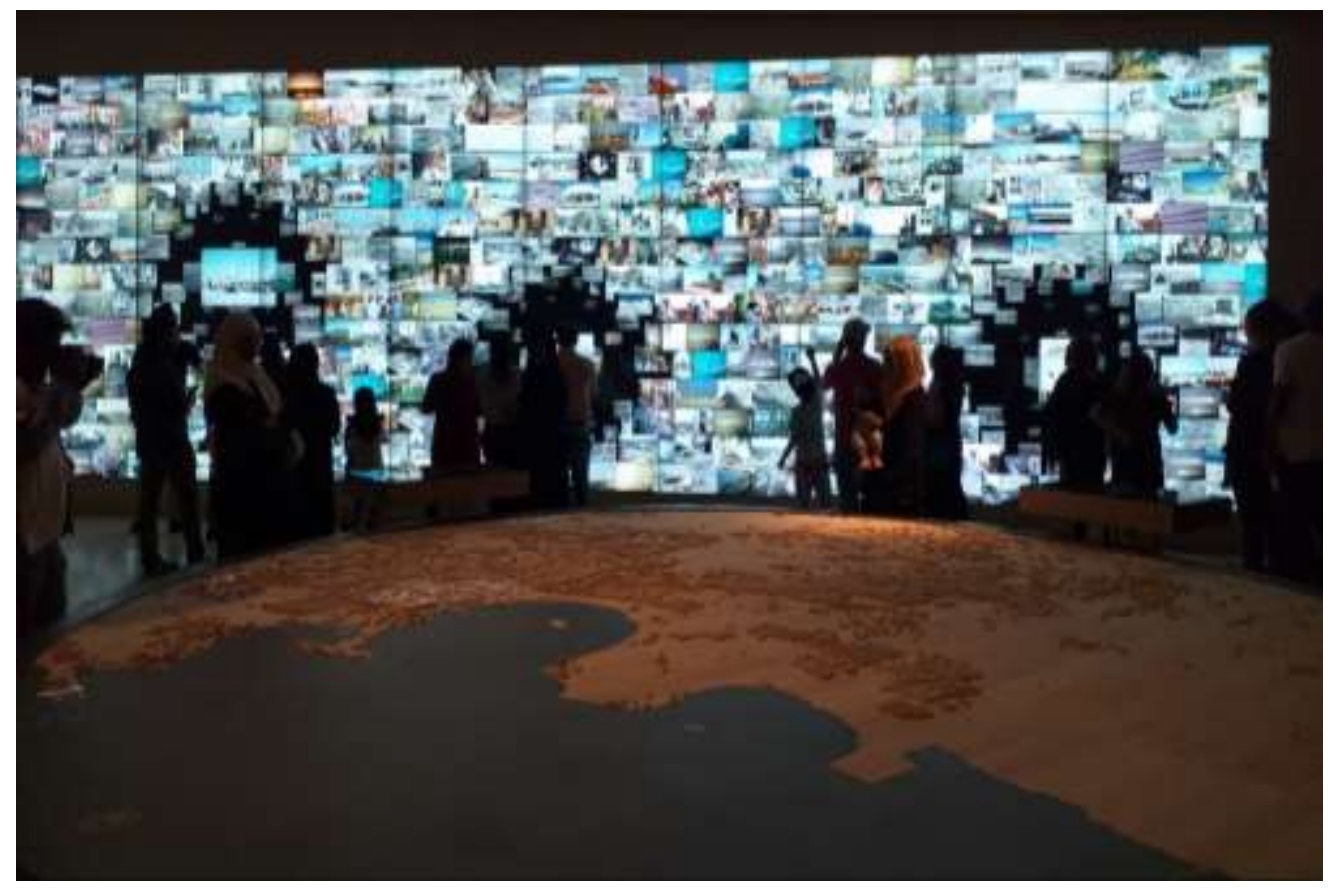

Görsel 8. Katar Ulusal Müzesi dijital fotoğraf ve bilgi platformu, 2019.

Ulusal Müze'yle birlikte Katar'ın dünyaya açılmasını amaçlayan agresif bir inşaat ve pazarlama stratejisi olan Turizm Master Planı ilan edilmiş; BAE'nin Dubai için izlediği politika benimsenerek 2004'ten itibaren ünlü otel zincirlerini Katar'a çekmek için 15 milyar dolarlık yatırım ve tanıtım çalışmaları yapılmış; yeni müzeler ve tema parkları 
oluşturulmuştur. Markalaşma yolundaki çabalar, 2006'dan itibaren düzenlenen Katar Kültür Festivali gibi toplumsal katılımı gerektiren çalışmaları da içermektedir. 2008'de İslam Sanatları Müzesi'nin açılması, 2010'da Arap Çağdaş Sanatlar Müzesi (Mathaf)'nin kurulması ve son olarak Katar Ulusal Müzesi'nin dünyada ses getiren bir ihtişamla ziyaretçiyle buluşması bu çabanın göstergeleridir. Bu müzelerin IM Pei ve Jean Nouvel gibi yıldız mimarlar tarafından tasarlanması da yatırımların boyutunu göstermektedir.

Müze ve sanat galerilerinin yanı sıra açılan uluslararası okullarla Katar'ı bir eğitim ülkesi haline getirmek de hedeflenmektedir. Devlet destekli Katar Eğitim, Bilim ve Toplum Gelişimi Vakfı himayesinde açılan üniversitelerin yanı sıra; Cornell Üniversitesi (tıbbi kolej); Virginia Commonwealth Üniversitesi (güzel sanatlar ve tasarım); Carnegie Mellon Üniversitesi (bilgisayar bilimi ve işletme), Georgetown Üniversitesi (dış ilişkiler) ve Rand Katar Politika Enstitüsü yerli ve yabancı öğrencilerin ilgisini çekmektedir. Londra Üniversitesi tarafından Katar'da açılan şubede Müze Çalışmaları ve Galeri Uygulamaları yüksek lisans programıyla gelişen Katar müzelerine ve ulusal miras çalışmalarına destek verecek donanımlı öğrenciler yetiştirmek amaçlanırken, uluslararası ölçekli müzecilik projeleriyle de uğraşılmaktadır. Orta Doğu'nun en büyük bilim ve teknoloji Parkı olmaya aday Katar Bilim ve Teknoloji Parkı da keşfe dayalı öğrenme etkinlikleri sunmanın yanı sıra ülkenin kendi teknolojisini geliştirmenin yollarını aradığının göstergesidir (Ouroussoff, 2010:5).

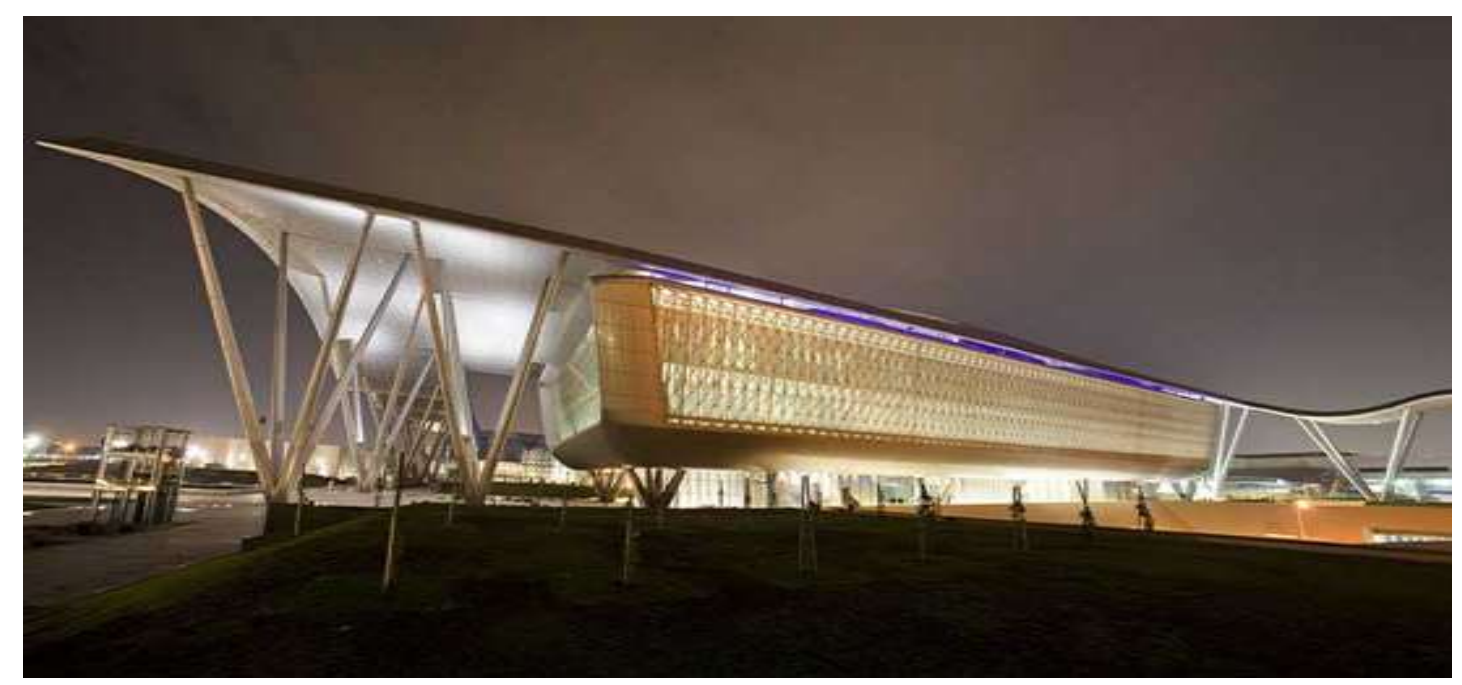

Görsel 9. Katar Bilim ve Teknoloji Parkı.

Ouroussoff (2010:5)'a göre, 2008 yılında ünlü mimar I.M. Pei tarafından tasarlanan Katar İslam Sanatları Müzesi (MIA) ve Jean Nouvelle tasarımı Doha'daki Katar Ulusal Müzesi gibi örneklerle, Abu Dhabi ve Dubai'nin aksine Katar, İslamı ve modernizmi bir 
araya getiren, daha programlı ve hesap edilmiş bir inşaat sürecine girmiştir. Mimar IM Pei MIA'da doğum yeri Suzhou'da tasarladığı geleneksel sanatlar müzesine çok benzeyen bir müze binası tasarlamıştır. Doha'nın corniche olarak adlandırılan sahil şeridi üzerinde inşa edilen MIA'nın mimarisinde çarpıı bir dikey ve çapraz çizgi dili göze çarpmaktadır. Binada her galeri etrafında yürüme yolları yer almakta ve her yol büyük bir avluya açılmaktadır. Avlunun hemen üzerinde iki katı da kaplayan büyük bir pencere izleyicilere deniz manzarası sunmaktadır. Dışarıdan, binanın şekli yekpare, içe dönük, güçlü ancak karmaşıktır. Ancak yapının içinde gözleri rahatlatan, birden fazla geometrik unsur İslam sanatındaki geometriden esinlenerek yerleştirilmiştir. Pratomo ve Provoost (2017)'a göre, binanın en çarpıcı özelliği zıtııklardan oluşmasıdır. Zıtlıkları birleştirmek PEI için nasıl mümkün olmuştur? Doha'da ne kadar çok gökdelen inşa etmiş olurlarsa olsunlar, PEI Doha'nın her zaman çölün kumlu rengine sahip olacağı gerçeğinden hareketle tasarımında bu doğal rengi kullanmıştır. Müze, Osmanlı, Abbasi, Emevi, İran, Azerbaycan, Hindistan, Pakistan, Irak ve Suriye egemenliğindeki İslam dünyasına ilişkin zengin cam, metal, tekstil, takı, resim, çini, ahşap ve astronomi koleksiyonuna sahiptir. Koleksiyonlar çağdaş müzecilik yaklaşımları çerçevesinde rahat izlenebilecek biçimde sade bir serimle farklı yüksekliklerdeki kaidelere yerleştirilerek yeterli içerikte bilgiyle, işitsel ve görsel metinlerle desteklenerek sergilenmektedir. Sergiye izleyicinin ayrıntılı bilgi almasını kolaylaştıracak dijital ve dokunmatik bilgi ekranları ile temalara vurgu yapacak içerikte videolar eklenmiştir. Müzenin mimarisi ve sergi tasarımının yanı sıra toplumsal işlevleri gerçekleştirmek için kurduğu müze eğitimi birimi aktif biçimde çalışmaktadır. Müze bu bağlamda öğretmenler, öğrenciler, yetişkinler ve aileler için koleksiyonla bağlantılı eğitim etkinlikleri hazırlamakta; müze rehberli turları düzenlenmekte, Suriye'nin mirası ve İslam'da bilim konulu müze öncesi ve sonrası atölye programları sunulmaktadır. Ek olarak müze tarafından İslam sanatı ve dekorasyon, İslam geometrisi ve İznik Çinileri konulu eğitim paketleri hazırlanmıştır. 
SDÜ ART-E

Güzel Sanatlar Fakültesi Sanat Dergisi

Aralık'19 Cilt:12 Sayı:24

ISSN 1308-2698

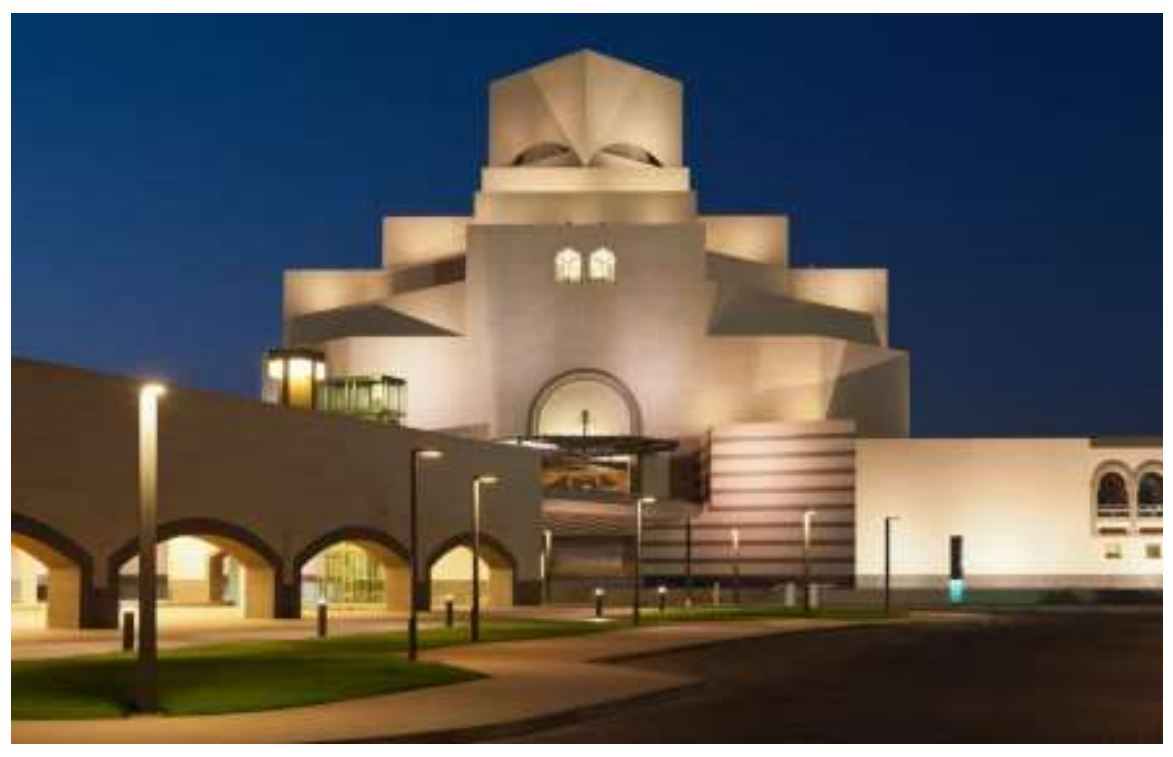

Görsel 10. Katar İslam Sanatları Müzesi, 2019.

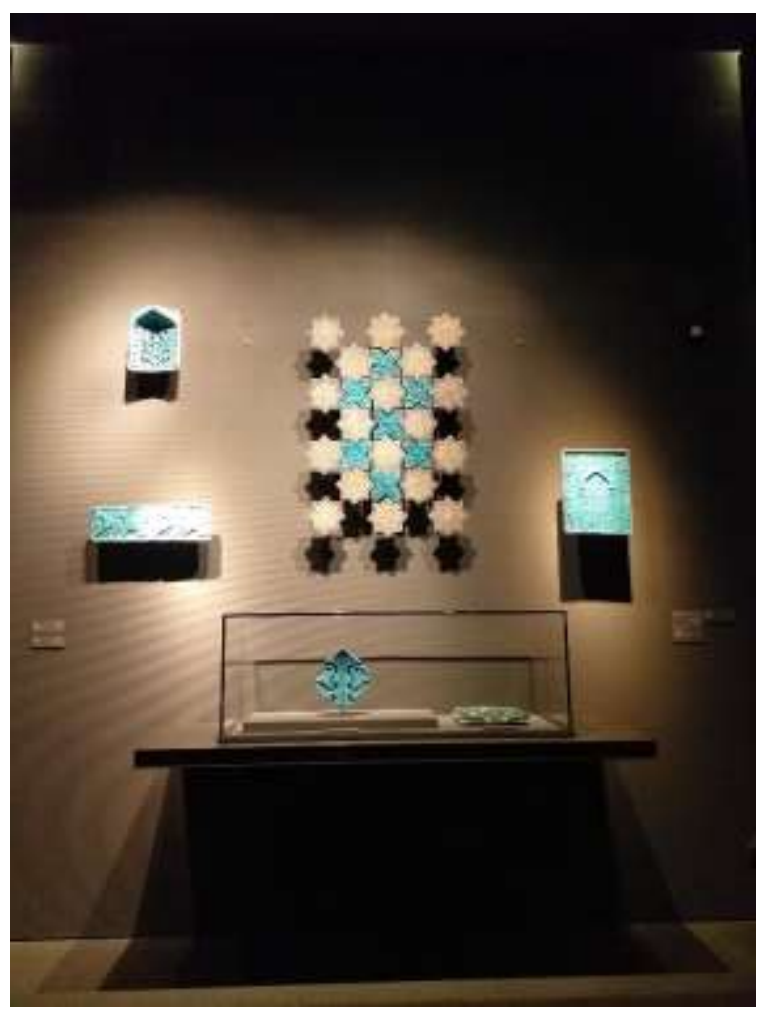

Görsel 11. Katar İslam Sanatları Müzesi, 2019. 
SDÜ ART-E

Güzel Sanatlar Fakültesi Sanat Dergisi Aralık'19 Cilt:12 Sayı:24

ISSN 1308-2698

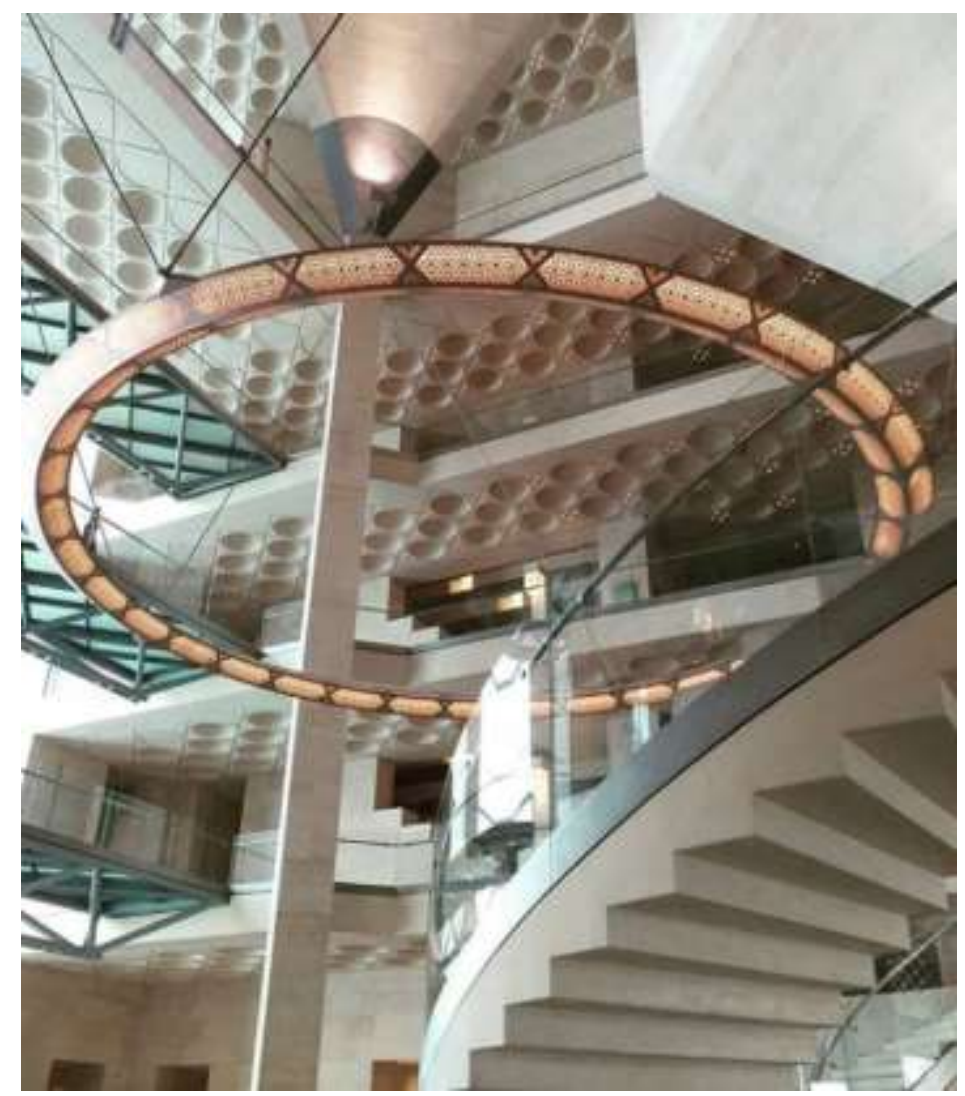

Görsel 12. Katar İslam Sanatları Müzesi tavan detayları, 2019.

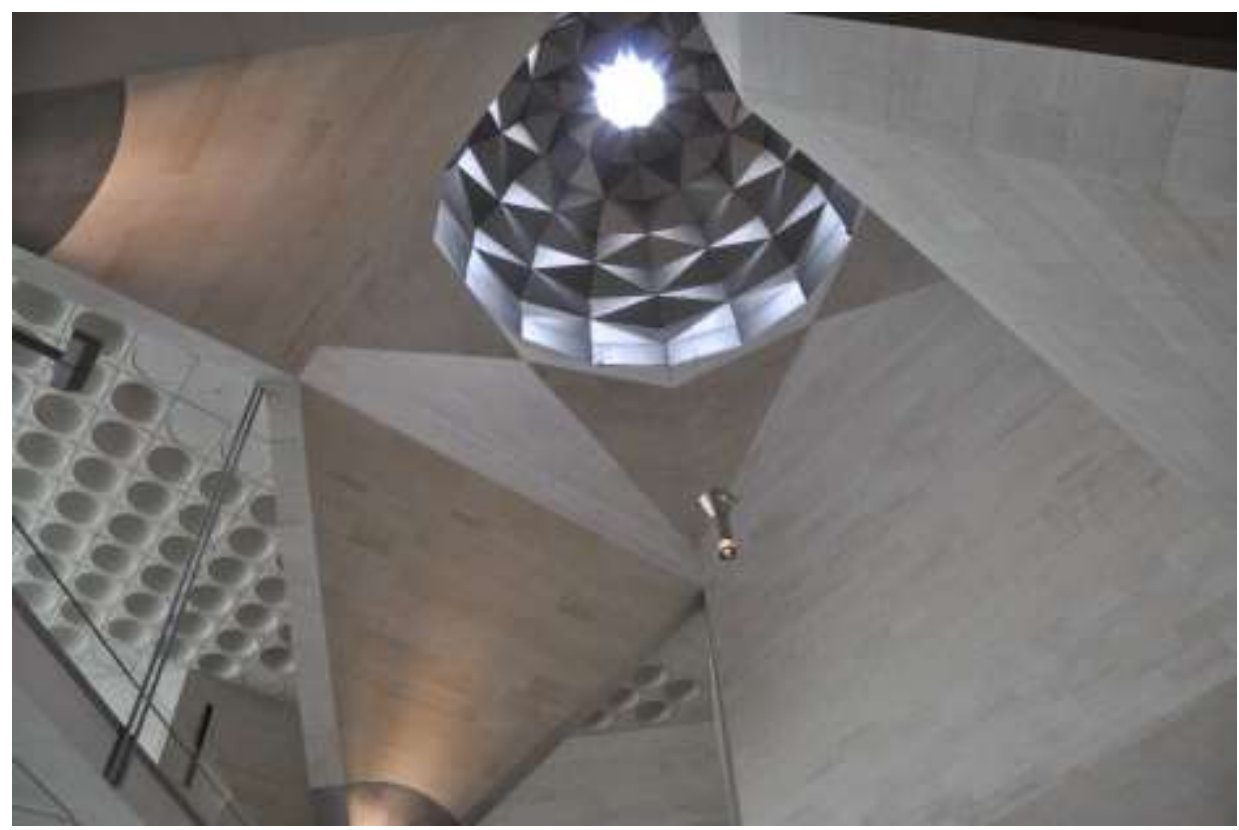

Görsel 13. Katar İslam Sanatları Müzesi tavan detayları, 2019. 
Katar ve BAE gibi Körfezin ekonomik bağlamda güçlü iki ülkesinde gerçekleştirilen kültür yatırımlarının büyük bölümü 11 Eylül sonrası gelişmelerden mümkün olduğunca az etkilenmek ve post-petrol döneminden güçlü biçimde çıkabilmek amacıyla yapılmıştır. Bu yatırımların en iddialılarından biri olarak suyun içinde sağlam bir doğal taş yapı gibi yükselen MIA, aynı zamanda Katar'daki ilk çarpııı müze yapısıdır. Nouvelle'in şaşırtıcı tasarımı olan Ulusal Müze'nin yeni binasının inşasına kadar Arap Körfezi'nin en ilgi çeken müze binalarından biri olmuştur.

Fransız mimar Jean-François Bodin tarafından tasarlanan Arap Çağdaş Sanatlar Müzesi (Mathaf) ise, MIA’nın aksine Arap Körfezi'nde Arap ulusal kimliğinin evrensel dünya sanatındaki yerinin sorgulanmasını sağlamak amacıyla, Doha'nın yeni ekonomi bölgelerinden biri olan Education City'de kurulmuştur. Mathaf'ın amacı hem tarihî hem de deneysel olan sanat sergilerini uluslararası bir platformda sunmaktır. Müzenin kalıcı koleksiyonu hem tarihî hem de modern Arap sanatından örnekleri içermektedir. 6000'in üzerinde esere ev sahipliği yap müzede sadece Katar asıllı değil, Lübnan, Mısır ve Fas asıllı sanatçıların çalışmalarına da yer verilmiştir. Mathaf, Katarlı genç sanatçıların yeni teknikleri deneyimledikleri; kavramsal sanat çalışmaları için iş birliğine dayalı bir ortam buldukları ve uluslararası sanat piyasası hakkında bilgi sağladıkları bir sanat platformudur. Mathaf, inşaasında kullanılan yerel taşlarla ve kemerli yapı özellikleriyle tarihi Katar evlerini simgelerken; müze bahçesine yerleştirilen büyük heykellerle İslam öncesi Arap topluluklarının çok tanrılı dini inançlarına da gönderme yapmaktadır. Müze, Arap sanatçıların eserlerinden oluşan sürekli sergisi dışında geçici sergiler açmakta; ulusal ya da uluslararası sanat etkinliklerinde üretilen çalışmalara ve atölyelere ev sahipliği yapmaktadır. Öğretmenler, öğrenciler, yetişkinler ve aileler için düzenlenen eğitim etkinlikleri arasında "sanat üzerine hikâye anlatıcılığı" önemli bir yer tutmakta ve yaşam boyu öğrenme etkinliği olarak vurgulanmaktadır. 


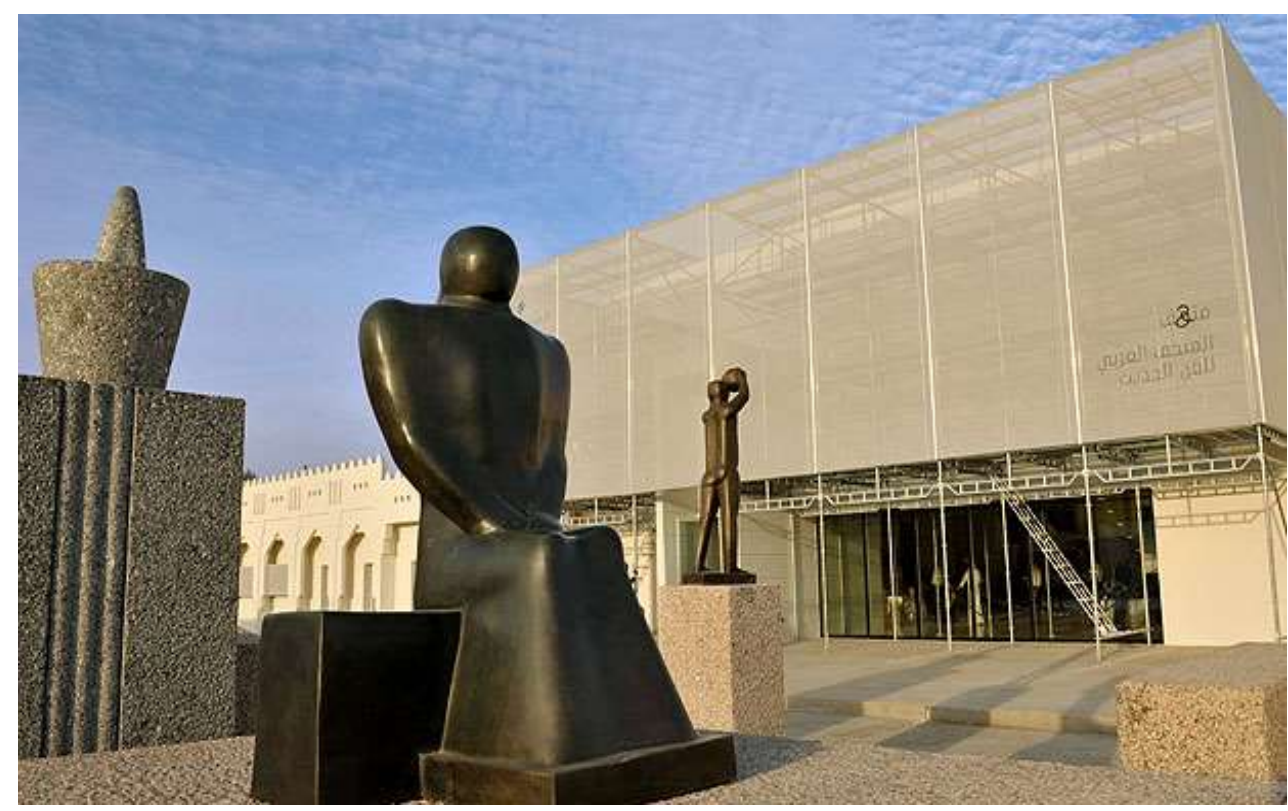

Görsel 14. Mathaf Çağdaş Sanatlar Müzesi.

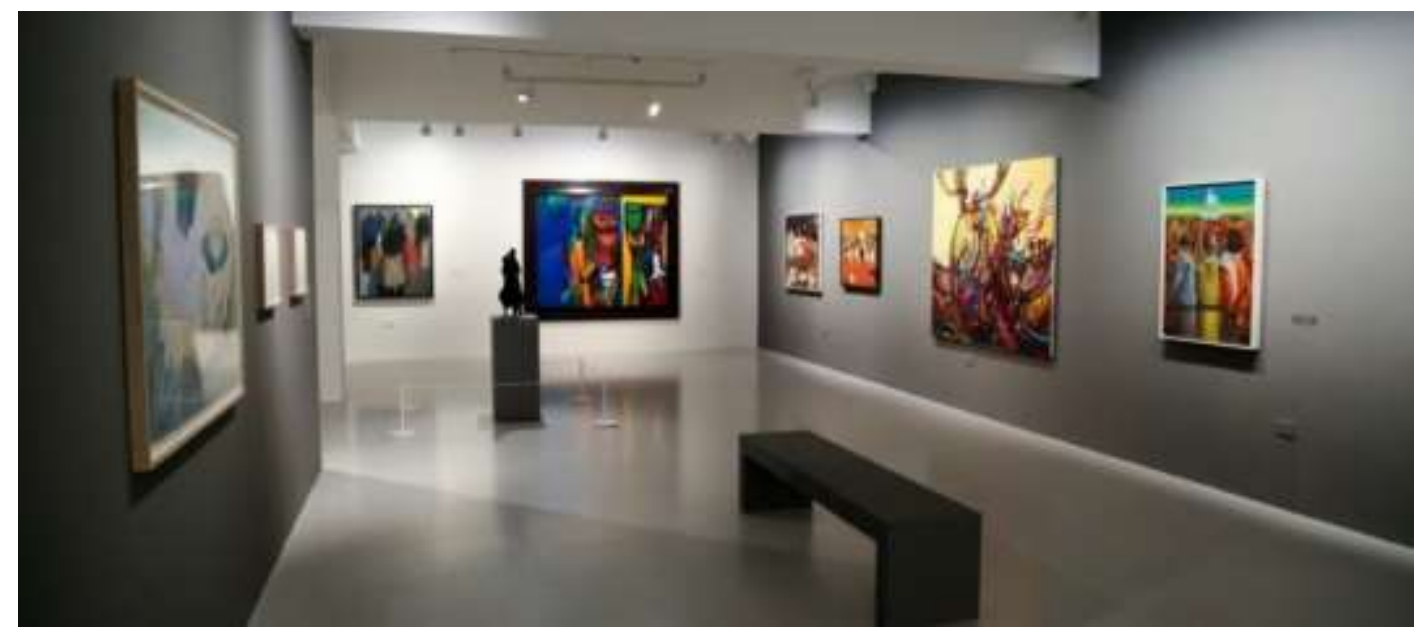

Görsel 15. Mathaf Çağdaş Sanatlar Müzesi ana galeri.

Exell (2016:261)'e göre, son on beş yılda Katar'da oluşturulan ve Batı sanatından eserler içeren koleksiyonlar "miras" söyleminin bir örneği olarak Katar'ın ulusal kimliğinin inşası, korunması ve sürdürülmesi sürecinde devam eden koleksiyon yönetimi ve küratörlük faaliyetlerinin çıktısıdır. Öte yandan Katar, sanat koleksiyonlarının zenginliği, çağdaş bir sanat müzesi açma ve yürütme girişimi ve çağdaş müzeleri finansal bağlamda desteklemesinin yanında sanatçı Hossenaly (2012)'e göre, ışıltılı ve hoşgörülü bir ülke olmanın ötesinde, tüm bu gelişmelere rağmen hala sert monarşiyle yönetilen, göçmenlerin ve kadınların haklarıyla ifade özgürlüğünün pek gözetilmediği bir ülke olduğu gerekçesiyle 
eleştirilmektedir. Bu durum ulusal kimliği evrensel etkinlikler aracılığıyla inşa etme çabaları içinde olan Katar'ın durumunun bir ikilem olarak kabul görmesine neden olmuştur.

\subsection{Katar'da Yeni Nesil Koleksiyonerlik ve Msheireb Kültür Bölgesi}

Miller (2008:7)'a göre, eski ve yeninin birlikteliği yankı hafızası kavramıyla açıklanabilir. Çağdaş müzelerde bu kavramın izlerini sürmek mümkündür. Örneğin, son yıllarda Katar müzeleri eski nesli temsil eden Katarlıların kişisel koleksiyonları ve yankı hafızası koleksiyonu tarafından temsil edilen Güney Asya göçmen işçi topluluğunun zor yaşam koşullarını ve deneyimlerini erişime açmaktadır. Eylül 2019'da Kyoto'da Uluslararası Müzeler Konseyi tarafından toplantıda müze tanımı yeniden ele alınmış ve müzelerin hiçbir ekonomik, sosyal ya da kültürel ayrımcılık yapmadan tartışmalı konuları gündeme getiren, demokratikleşme kurumları oldukları vurgulanmıştır. Müzeler önceliği eğitime vermeli ve toplumun dışlanmış kesimlerini geliştirmelidir. Müzelerin izleyiciler tarafından nasıl kullanıldığının daha çok önem kazandığı yeni müzecilik yaklaşımlarında toplumun her kesimini ilgilendiren konuların gündeme gelmesi müzenin önemini de gözler önüne serecektir.

Hooper-Greenhill (2007:16)'e göre, 21. yüzyılın başında müzeler ne olabileceklerine ilişkin yenilikleri düşlemleyerek kendilerini yeniden yönlendirmektedir; bildik uygulamalar yeniden değerlendirilmekte ve eski felsefeler artık aşılmaktadır. Kültüre ve topluma ilişkin yeni fikirler ve yeni politika girişimleri müzeleri kendi amaçlarını yeniden düşünmeye, performanslarını değerlendirmeye ve pedagojilerini yeniden tasarımlamaya zorlamaktadır. Bu bağlamda ulusal kültürün en önemli unsurlarından biri olarak kabul edilen modern müze, yerini kimliği yaratıcı bir biçimde yeniden düşünen postmodern bir kuruma bırakmıştır. Buna göre, Torch (2010:7)'a göre, postmodern müzeler, yalıtılmış ve akademik temelli kurumlardan ortak kültürel belleğin ulaşılabilir merkezlerine dönüşmüşlerdir. Müzeler arşiv yapmaktan çok iletişime odaklanarak, sadece geniş toplumla değil aynı zamanda tanımlanmış hedef gruplarla (göçmenler, küresel göçerler, öğrenciler) ve bireysel ziyaretçilerle aktif bir diyaloğa açılmışlardır.

Postmodern yaklaşımın yeni müze işlevlerine vurgu yapması Katar'da farklı içerikteki koleksiyonların çarpııı biçimde sergilenmesini gündeme getirmiştir. Bu sergiler içinde Katar'ın demografik ve kültürel değişimine vurgu yapan ve 2009-2011 yılları arasında gerçekleştirilen Başka Bir Tarih: Anıların Yankısı Projesi'dir. Projeyle koleksiyon nesnelerinin 
Katar Ulusal kültürünü vurgulayııı biçimde temsil edecek kurgular oluşturmak amaçlanmış; örneğin kahve takımları vb. ilk kez Batılı bir anlayışla sergilenmeye başlanmış, nesne tarihleri ayrıntılı olarak araştırıııı̧, yorumlanmış ve toplumsal yaşantının izleri kayıt altına alınmıştır. Bu sergi projesinin çıkış noktası Katar'ın önüne geçilmez yükselişine imza atan göçmenlerin kültürel, sosyal ve dini yaşam biçimleridir. Ulus ötesi küresel göç diğer Körfez ülkelerinde olduğu gibi Katar'ın postmodern yapısını oluşturan en önemli olgudur. Ülke nüfusunun yüzde $88^{\prime}$ i sadece oturma izni bulunan, farklı sektörlerde çalışan ve "expat" olarak adlandırılan göçmenlerden oluşmaktadır. Bununla birlikte vatandaşlık alamamalarına rağmen özellikle Asya ülkelerine mensup göçmenlerin birkaç kuşaktır Katar'da bulunmaları ülkenin kültürünün şekillenmesinde de etkili olmuştur.

Göçmen topluluklar planlı müze sergilerine ve müzelerdeki kültürel etkinliklere kısmen konu edilse de Doha'nın bazı bölgelerini kültürel olarak iz bırakmakta ve kültürel değişime neden olmaktadır. 2015 yılında Doha kent merkezinde yer alan Msheireb Bölgesi'ndeki dört kültür ve miras evi göçmen öykülerini anlatan sergi ve etkinliklere örnek oluşturacak ilk çalışmaları başlatmışlardır. Katar'ın Körfez'de önemli bir güç olma politikasının en büyük parçalarından biri aynı zamanda bir sanat bölgesi olarak da kabul edilen Msheireb Bölgesi'nin geliştirilmesidir. Msheireb'in yenilenmesi, şehir merkezinde yer alan Güney Asya topluluklarının yaşadığı yoğun ticaret bölgesinden hareketli ve çağdaş bir kentsel alana dönüşme amacının bir parçasını temsil etmektedir. Bölge, 1939'da İngiliz koruyuculuğu döneminde (1916-1971) petrolün keşfedilmesiyle birlikte hızlı kentleşmeye sahne olmuştur. 1960'dan itibaren, Hindistan, Nepal ve Bangladeş'ten gelen göçmen işçiler, banliyölere taşınarak Katarlı toprak sahiplerinin mülklerini kiralamışlardır (Kapiszewski, 2016:47). Bu hareket, Katar'ın millileştirme vizyonu kapsamında Katar vatandaşı olmayanların hak kaybının boyutlarını da gündeme getirmiş; aynı zamanda göçmenlerin yeni kültüre uyum sağlama konusunda gösterdikleri direnci gözler önüne sermiştir. Bölgede 1950'lerde bir okulun restore edilmesiyle kurulan Msheireb Sanat Merkezi (MAC), Güney Asyalı toplulukların yaşamlarını büyük ölçüde temsil eden nesnelerden oluşan sergiler açmış, Anıların Yankısı gibi ses getiren çalışmalara ev sahipliği yapmıştır. Bobby Lloyd ve Sally Labern adlı iki İngiliz Sanatçının yanı sıra İngiliz mimar Tim Makower’ın da çalıştığı projede sergilenecek nesneler Msheireb Sanat Merkezi'nde çalışan sanatçılar tarafından seçilmiştir. 
Koleksiyon, Lloyd ve Labern tarafından geliştirilen bir yöntem ve tipoloji izlenerek 2009-2011 yılları arasında dört aşamada göçmenlerden toplanmıştır. Metodoloji, her binayı numaralandırmayı ve aynı sayıyı o binada bulunan nesnelere eklemeyi içermiştir. Toplama sürecindeki odak, nesnelerin sahibi olan ve o nesneleri kullanan insanlardan ziyade, nesnelerin toplandığı alanlardır. Projede Lloyd ve Labern, koleksiyonun yapılandırılması için göçmenlere ilişkin şu nesneleri toplamışlardır: Kapılar, panjurlar, ekranlar, mimari elemanlar, yapı malzemeleri-metal, kereste, ağaç gövdeleri, tabela-mağaza işaretleri ve sokak levhaları, ev/apartman numaraları, ışık tertibatı, sandalyeler, masalar, dolaplar, ocaklar, buzdolapları vs. elektrikli aletler ve çeşitli araçlar, çiviler, vidalar, çarklar vs. renkli cam eşyalar, konteynerler, kutular, paketler, valizler, sanat malzemeleri, şapkalar, ayakkabılar, eldivenler, çamaşırlar, kitaplar, afişler ve reklamlar, fotoğraflar, oyuncaklar, bellek belgeleri- kişisel koleksiyonlar, arabalar, su tankları vb.

Koleksiyon oluşturulurken 4000 'e yakın nesne toplanmıştır. Koleksiyonun niteliği, projenin amacı ile ilişkilendirilmiştir. Bu projeyle, Katarlı sanatçıların yeni Msheireb Bölgesi'nin gelişiminde kurulacak sanat alanlarında çalışmalarını sağlamak, yeni eserler oluşturmaları için olanaklar yaratmak ve yeni nesneler oluşturulmak da amaçlanmıştır. Bu nesnelerin kendi başlarına kendine özgü bir değeri yoktur, ancak her biri Katar kültür tarihi açısından birer kültürel hızlandırıcıdır, çağdaş sanatsal ifadeler için araçtır ve yeni Katar kimliğinin çağdaş birer ifadesidir (Barbour, 2012). Lord (2007:8)'a göre, çağdaş müze ve galeriler hazırladıkları sergilerle toplumsal değişim konusundaki farkındalığımızı artııılar, bu nedenle kültürel hızlandırıcı olarak kabul edilirler. Sergi için toplanan bu nesneler aynı zamanda Msheireb Bölgesi'nin geçmişini, burada yaşananları, göçmenlerin kurduğu yeni Katar'ı ve onların geleceğe ilişkin umutlarını da temsil etmektedir. Bir Güney Asya anlatısına yapılan bu sıradan vurgu, koleksiyonun oluşumunda ve kullanımında rol alan veya yorum yapan kişilerin etkisiyle artmıştır. Sergiye ilişkin Fox (2012:80-81), sergilenen nesnelerin "yazılmamış yerel tarih ile dolu ihmal edilen eşyalar" olduğunu vurgulamıştır. Bu sergiyle birlikte, haklarından mahrum edilmiş kaynak toplulukların yalnızca Katar'da sahip olmak istedikleri gelecek için mülklerin yeniden kullanımına ilişkin önemli gelişmeler de yaşanmıştır.

Msheireb Sanat Merkezi'nde yer alan “Msheireb'in Anıları" galerisinde Doha'da erken yerleşim: 1930 'lar-1950'ler, Doha'da etkinlikler ve kutlamalar, Doha ve elektrik, 
Doha'da ticaret ve Sağlık ve eğitim gelişmelerini anlatan kapsamlı bir sergi oluşturulmuş ve mekân kent tarihi müzesi görünümüne kavuşmuştur. Sergi, tema ile bağlantısı için seçilen nesneleri farklı sergi tasarım ürünleriyle birlikte sunarken, aynı zamanda, sadece kronolojiye sıkı sıkıya uymak yerine, nesnelerin estetik çekicilikleri üzerine yoğunlaşmıştır (Buchli ve Lucas, 2001:161). Katar'da “dışlanmış toplulukların” günlük yaşam nesnelerinin sanat objeleri olarak meşrulaştırılarak sunulması ve bir müze sergisi gibi sunumu yüzeysel görünebilir, ancak Katar gibi sıkı kontrol edilen siyasi bir ortamda, resmi olarak "görünmez" bir topluluğun temsil edilmesi ilgi çekicidir. Nesneler politik söylemlerinden arındırılmış ve miras politikaları aşılarak, Katar tarihinin alternatif anlatımının sınırları içerisinde var olabilmiştir.

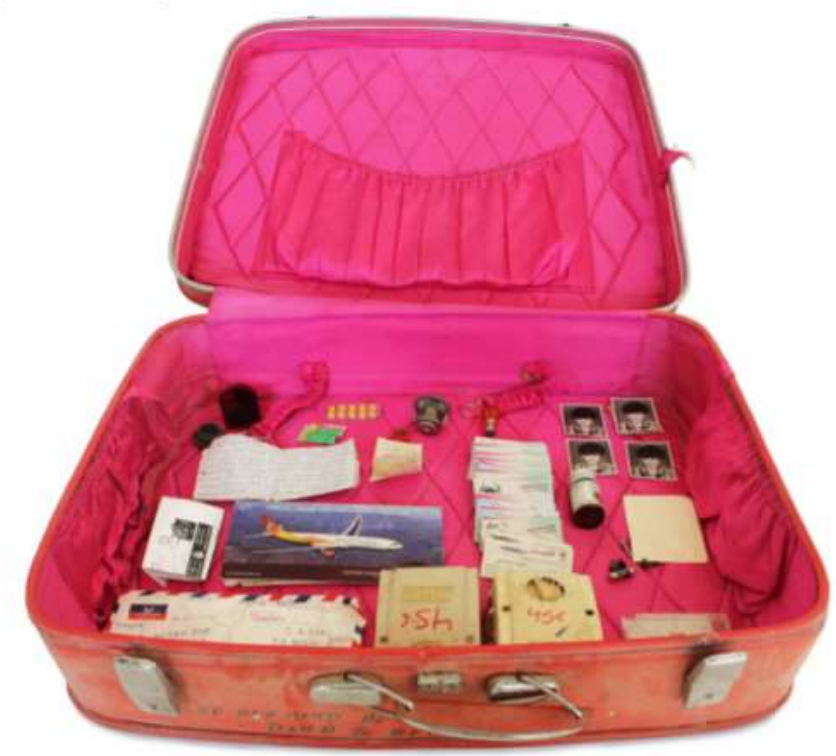

Görsel 16. Bombay'dan Doha'ya pembe bavul, Msheireb Sanat Bölgesi'ndeki 456 numaralı binada sergilenen bir göçmen bavulu, 2014.

\section{Değerlendirme ve Sonuç}

Katar'da diğer Körfez ülkelerinde olduğu gibi 1970'den sonra petrole dayalı endüstrinin kalkınmayı biçimlendirmesiyle aidiyet, ulus ve kimlik inşası gündeme gelmiş; ülke genelinde arkeolojik kazıların başlatılmış, geçici sergiler düzenlenmiş ve müze vb. kültür ve miras kurumları açılmıştır. Bu gelişmelerden hareketle Katar'da ulusal kültürü yansıtacak, aynı zamanda çağa uygun, evrensel kültürle bütünleşecek ve yeni müze tanımını karşılayacak müzeler kurmak, çeşitlilik içeren izleyici kitlelerini kültür kurumlarına 
çekebilmek; yerel halkın kültür, bilim ve sanata ilgisini artırmak ve kültür, bilim ve sanat alanında etkileşimli deneyimler sunmak öncelikli politika haline gelmiştir.

Katar ulusal mirasının, müzeler ve arkeolojik alanlar aracılığıyla Katar ulus kimliğinin karmaşıklığını yansıtan miras yapılarına değinerek, sözlü gelenek ile geçmişin ve bugünkü kimliğin güçlü söylemlerle anlatılması üzerine kurgulanması evrensel ölçekte müze sayısının artmasına neden olmuştur. Karp vd. (2006), çağımızda küresel miras yönetiminde ve müzecilikte uluslararası bağlantıların kurulduğu ve küresel oryantasyonların uygulandığı iş birliğine dayalı bir dönem yaşandığını, bu gelişmelerin farklı ülkelerde benzer özellikler taşıyan "evrensel” müzeleri doğurduğunu vurgular. Marka haline gelebilecek bir evrensel müze açmak postmodern kültürde ulusal kimliklerin en güçlü söylemle gündeme getirilebilmesinin ön koşuludur. Aynı zamanda müzeler kimlik temsiline olanak sağlayan mekânlar olmanın ötesinde, çağdaş dünya kimliğini de ilgililerle doğrudan buluşturma özelliğine sahiptir. Bu bağlamda Katar, komşusu BAE'deki gibi ulusal kültür inşası süreci olarak bilinen "Emirileştirme" politikası doğrultusunda kurulmuş "evrensel" müzelerin benzerlerini kurmaya soyunmuştur. Bu müzeler zamanla ulusal kültür tanıtımının ötesine geçerek Arap Körfezi'ndeki turistik yatırımlarının artması, yeni çekim ve cazibe şehirlerinin oluşturulması gibi nedenlerle ülke turizminin gelişimini doğrudan etkileyen kurumlar haline gelmişlerdir (McClellan, 2012). Bu saptamadan hareketle Katar'ın petrol endüstrisine alternatif bir kültür ve eğlence turizmi oluşturmayı başardığı söylenebilir.

Katar müzecilikte BAE ile benzer bir politika izlemekte ancak bu süreçte BAE'deki müzelerin aksine (Louvre Abudhabi vb.) müze gibi ulusal kimliği öne çıkaran kurumlarda daha geleneksel bir içerik geliştirmeye çalışmaktadır. BAE'de ziyarete açılan Louvre Abudhabi ve açılışına kısa bir süre kalan Guggenheim gibi ulus ötesi ortaklıkların ve neoliberal kültür politikalarının sonucu olan müzelerden ziyade, ulusal koleksiyonların ülkenin öyküsünü anlattığı Katar Ulusal Müzesi veya Orta Doğu, Orta Asya ve Hindistan'dan gelen nesnelerle oluşturulmuş, İslam kültürünü en çağdaş biçimde temsil ettiği iddia edilebilecek MIA gibi yerel kodlara ve dinamiklere sahip müzeler kurmak Katar'ın geleneksel dokuyu sürdürme amacını göstermektedir. Yine de bu durum Körfez ülkelerinde birbiri ardına tanıtılan ilgi çekici mimari tasarımların müze koleksiyonlarının değerini artırdığı söylemini ortadan kaldırmış değildir. Bu nedenle ki, ülkede ses getirecek ve Katar'ı uluslararası kültür 
ve sanat yarışında önemli ve kazanan bir aktör haline getirecek mimari proje çalışmaları sürmektedir.

Müzecilik çalışmalarının yanı sıra Katar'ın mirasını belgelemek, sanat piyasasının ritmini yakalayacak kültür ve sanat çalışmalarına ev sahipliği yapmak ve bilimsel kültürel miras çalışmalarına yer vermek de Katar'ın izlediği ulusal politikanın önemli parçalarıdır. Batı'nın ilgisini çeken Katar miras çalışmaları ard arda ilan edilmektedir. Los Angeles'taki postmodern sanat müzesi ile tanınan mimar Arata Isozaki tarafından "Sidra Ağacı" biçiminde tasarlanan Katar Ulusal Kütüphanesi, Kongre ve Gösteri Merkezi binası ses getiren miras çalışmalarından biridir. Isozaki Katar’a özgü Sidra Ağacını çölde dalları altında dinlenilecek bir mekân olarak tasarımını biçimlendirirken kullanmış, aynı zamanda ağacı dalları altında dinlenen şairler ve bilginlerle değerlenen bir canlı varlık olarak somutlamıştır. Belediye ve Şehircilik Bakanlı̆̆ı'nın isteğiyle başlatılan bir diğer projede ise yine ünlü mimar Santiago Calatrava tarafından "Sharq Geçidi" isimli bir köprü projesi başlatılmıştır. Başarılı bir mühendislik ile ikonik bir tasarımın birleşimi olarak kabul edilen, Havaalanı bölgesiyle West Bay Finans Bölgesi ve Kültür Şehrini birbirine bağlayacak olan bu büyük köprünün Katar’ın turizm gelirlerini artıracağı ön görülmektedir (Sherwood, 2006).

Arap Körfezi'ndeki Birleşik Arap Emirlikleri, Umman, Bahreyn, Kuveyt ve Suudi Arabistan gibi diğer ülkelerin uluslararası turizm pazarından pay alma çabalarının ve pazardaki rekabetin şaşırtıcı derecede artmasıyla Katar, kültürel mirasını koruma, geliştirme ve sürdürme çabaları gösterirken bir yandan da göçmen bakımından zengin, farklı ve hiyerarşik kültürünü müzeler ve sanat kurumları aracıllğıyla görünür hale getirmeye çalışmaktadır. Ancak müze sergileri ve hatta açılan müze türleri izlendiğinde göçmenlerin kültürünün ne düzeyde göz önünde bulundurulduğu tartışmalıdır. Oysa göçün de etkisiyle zengin bir kültürel çeşitliliğe sahip olan Katar'da halkın birlikte çöl ortasında bir Sidra ağacının altında bir arada oturma çabalarını anlatmak çağdaş Katar müzelerinin öncelikli amacı olabilir. Msheireb Sanat Bölgesi'nde oluşturulan galerilerde çarpıcı biçimlerde ve gündelik yaşam nesneleriyle sunulan göçmen kültürünü farklı platformlarda da ele almak Katar'ın 1970'den günümüze yaşadığı değişimi gözler önüne serecek; özellikle üçüncü dünya ülkelerine mensup göçmenlerin olumsuz yaşam ve çalışma koşulları hakkında aldığı eleştirilere cevap vermesini sağlayacaktır. Bununla birlikte, hem modern bir ulus olmak isteyen hem de Arap mirasını canlı tutmak amacıyla ulusal koleksiyonlara ses getirecek 
müze binalarına yer veren Katar'da $B A E^{\prime}$ de olduğu gibi, müzelere ve sergilere gidenlerin büyük çoğunluğu ya turist ya da ülkede yaşayan yabancılardır. Bu istatistikler ulusal kimlik inşasını kültür ve sanat üzerinden gerçekleştirmeye çalışan Katar'ın Christie's müzayede evinin eski başkanı Edward J. Dolman'ın rehberliğinde yüksek fiyatlara sanat eseri satan müzayede evleri ve sanat galerileri açmaya başladığını, refah düzeyi yüksek yabancılara ve Katarlılara hitap etmeye çalıştığını göstermektedir. Dolayısıyla Katar'ın kültür ve sanat bileşenleri doğrultusunda kurmaya çalıştığı ulusal kimliği Katarlı olmayan ünlü mimarlar ve sanat yöneticileri eliyle yabancı izleyicileri de tatmin edecek biçimde inşa edilmeye çalışıldığı görülmektedir.

2017 yılında, Katar'ın Orta Doğu'yu istikrarsızlaştıran "radikal örgütlere finansal kaynak sağladığı" iddiaları üzerine, Suudi Arabistan ve Körfez'deki müttefiklerinin ülkeyle diplomatik ilişkileri kesmesinin ardından sarsılan imajın düzeltilmesi için kültür, sanat ve spor alanlarında daha yeni girişimlerin hayata geçirildiği bilinmektedir. Yeni müzelerin inşası ile kültür, spor ve sanat atılımlarındaki amaç sadece Katar'ın olumsuz imajını ortadan kaldırmak değildir, aynı zamanda 21. yüzyılda yükselen değerler olan Çin ve Hindistan'ın yanında yer alarak yeni, popüler ve Avrupa kültürüne alternatif olacak bir ipek yolu turizm rotası da oluşturmaktır. Alternatif ipek yolunda söz sahibi olmak isteyen ve imaj düzeltme çalışmalarına ağır veren Katar'ın 2022 Dünya Kupası için başlattığı hazırlıkların kitleleri Sidra Ağacı altında birleştirip birleştiremeyeceğini ise zaman gösterecektir.

\section{Kaynakça}

Abdi, K. (2007). "The Name Game: The Persian Gulf, Archaeologists, and the Politics of Arab-Iranian Relations", Selective Remembrances: Archaeology in the Construction, Commemoration, and Consecration of National Pasts içinde, ed. Phil L. Kohl, Mara Kozelsky and Nahman Ben-Yehuda, Chicago, IL: University of Chicago Press, p.206-243.

Al-Mulla, I. M. (2013). Museums in Qatar: Creating Narratives of History, Economics and Cultural Co-Operation, Unpublished Doctor of Philosophy, UK: the University of Leeds: School of Fine Art, History of Art and Cultural Studies.

Artun, A. (2015). Çağdaş Sanatın Örgütlenmesi, İstanbul: illetişim Yayınları.

Artun, A. (2017). Mümkün Olmayan Müze, İstanbul: illetişim Yayıncılık.

Barbour B. (2012). Salvaging Memory: The Msheireb Arts Centre (MAC) and the Echo Memory Project, Unpublished Essay, United States of America. 
Bouchenaki, M. (2011). "The Extraordinary Development of Museums in the Gulf States", Museum International, 63(3-4), p.93-103.

Buchli, V. and Lucas, G. (2001). "The Archaeology of Alienation: A Late Twentieth Century British Council House", The Archaeology of the Contemporary Past, ed. Victor Buchli, London: Routledge, p.158-167.

Exell, K. (2016). "Desiring the Past and Reimagining the Present: Contemporary Collecting in Qatar", Museum \& Society, 14 (2), p.259-274.

Exell, K. ve Rico, T. (2013). "There is No Heritage in Qatar: Orientalism, Colonialism and Other Problematic Histories", World Archaeology, 45 (4), p.670-685.

Fibiger, T. (2011). "Global Display-Local Dismay: Debating "Globalized Heritage" in Bahrain", History and Anthropology, 22 (2), p.187-202.

Hooper-Greenhill, E. (2007). Museums and Education, Purpose, Pedagogy, Performance, UK: Routledge.

Kapiszewski, A. (2016). "Arab Versus Asian Migrant Workers in the GCC Countries", South Asian Migration to Gulf Countries: History, Policies, Development, ed. Prakash C. Jain, Ginu Zacharia Oommen, UK: Routledge, p.46-70.

Karp, K., Kratz, C. A., Szwaja, L. and Ybarra-Frausto, T. (2006). Museums Frictions: Public Cultures, Global Transformations, ed. Ivan Karp, USA: Duke University Press.

Kazerouni, A. (2014). Mirrors of the New Order: Museums in the Arab Principalities of the Persian Gulf between 1991 and 2011, Unpublished Lecture, 19th Dar al-Athar al-Islamiyyah Cultural Season, January, Kuwait: Al Maidan Cultural Centre.

Lord, G. D. (2007). "Museums, lifelong learning, and civil society", The Manuel of Museum Learning, ed. Lord, B., New York: Alta Mira Press, p.5-9.

Mason, R. (2006). "Cultural Theory and Museum Studies", A Companion to Museum Studies, ed. S. McDonald, p.17-32, UK: Blackwell Publishing.

McClellan, A. (2012). "Museum Expansion in the Twenty-First Century: Abu Dhabi", Journal of Curatorial Studies, 1(3), p.271-293.

Merrick, J. (2019). Desert Rose, Oryx, May, p.62-68, Qatar: Qatar Airways.

Miller, D. (2008). The Comfort of Things, Cambridge: Polity Press.

Peterson, E. J. (2006). "Qatar and the World: Branding for a Micro-State", Middle East Journal, 60 (4), p.732-748.

Raban, J. (1987). Arabia Through the Looking Glass, UK: Pan Books Ltd. 
Rice, M. (1977). “National Museum of Qatar, Doha”, Museum International, 29 (2-3), p.7887.

Talboys, K. G. (2006). Museum Educator's Handbook, (2nd ed.), England: Ashgate Publishing.

Torch, C. (2010). European Museums and Interculture, Responding to Challenges in a Globalized World, European Council Report, Sweden: Stockholm.

Ulrichsen, K. C. (2011). Insecure Gulf: The End of Certainty and the Transition to the PostOil Era, London: Hurst and Company.

Wright, S. (2011). "Qatar", Power and Politics in the Persian Gulf Monarchies in, ed. Christopher Davidson, London: Hurst and Company, p.113-133.

Yıldırım, A. ve Şimşek, H. (2006). Sosyal Bilimlerde Nitel Araştırma Yöntemleri, Ankara: Seçkin Yayıncılık.

Zahlan, S. R. (1989). The Making Modern Gulf States: Modern Gulf States, London: Billing and Sons Ltd.

\section{Internet Kaynakları}

Artun, A. (2014). "Sanatın Özerkliği Üzerine”, http://www.aliartun.com/yazilar/sanatinozerkligi-uzerine/, Erişim tarihi: 06.07.2019.

Batty, D. (2012). "The Rise of the Gulf Art Scene", The Guardian, 16 April, https://www.theguardian.com/artanddesign/2012/apr/16/rise-of-gulf-art-scene, Erişim tarihi: 10.08.2019.

Hossenally, R. (2012). "Qatar's Royal Patronage of the Arts: Glittering but Empty", New York Times, 29 February, http://www.nytimes.com/2012/03/01/world/middleeast/qatars-royalpatronage-of-the-arts-glittering-but-empty.html?pagewanted=all\&_r=0, Erişim tarihi: 07.08.2018.

Merrick, J. (2008). "Xanadu Reborn: New Museum of Islamic Arts", The Independent, 25 November, https://www.independent.co.uk/artsentertainment/architecture/xanadureborn -new-museum-of-islamic-art-1033645.html, Erişim tarihi: 10.06.2019.

Ouroussoff, N. (2010). "Building Museums and a Fresh Arab Identity", The New York Times, 26:1 - 6, https://www.3quarksdaily.com/3quarksdaily/2010/11/building-museums-and-afresh-arab-identity.html, Erişim tarihi: 16.09.2019.

Pratomo, W.; Provoost, K. (2017). "Why IM Pei's Museum of Islamic Art is the Perfect Building to Suit Doha's Style?", ArchDaily, 6 March, https://www.archdaily.com/867307/ why-im-peis-museum-of-islamic-art-is-the-perfect-building-to-suit-dohas-style, Erişim tarihi: 07.06.2019. 
Sherwood, S. (2006). "Is Qatar the Next Dubai?", The New York Times, https://www. nytimes.com/2006/06/04/travel/04qatar.html?pagewante, Erişim tarihi: 10.05.2019.

\section{Görsel Kaynaklar}

Görsel 1. Qatar Museums 2019, http://www.qm.org.qa/en Erişim tarihi: 27.09.2019.

Görsel 2. Ceren Karadeniz arşivi, 2019.

Görsel 3. Louvre Abu Dhabi Museum 2019, https://www.louvreabudhabi.ae/?utm_source= GMB\&utm_medium=organic\&utm_campaign=louvre-abu-dhabi, Erişim tarihi: 27.09.2019.

Görsel 4. Ceren Karadeniz arşivi, 2019.

Görsel 5. Ceren Karadeniz arşivi, 2019.

Görsel 6. Ceren Karadeniz arşivi, 2019.

Görsel 7. Ceren Karadeniz arşivi, 2019.

Görsel 8. Ceren Karadeniz arşivi, 2019.

Görsel 9. Woods Bagot Architects, 2011, https://www.e-architect.co.uk Erişim tarihi: 10.09.2019.

Görsel 10. Ceren Karadeniz arşivi, 2019.

Görsel 11. Ceren Karadeniz arşivi, 2019.

Görsel 12. Ceren Karadeniz arşivi, 2019.

Görsel 13. Ceren Karadeniz arşivi, 2019.

Görsel 14. Mathaf, 2019, http://www.mathaf.org.qa/en/ Erişim tarihi: 09.110.2019.

Görsel 15. Mathaf, 2019, http://www.mathaf.org.qa/en/ Erişim tarihi: 09.110.2019.

Görsel 16. Msheireb Sanat Bölgesi, Erişim Kaynağı: Exell, K. (2016), Modernity and the Museum in the Arabian Peninsula, London and New York: Routledge, Erişim tarihi: 25.09.2019. 